NBER WORKING PAPER SERIES

\title{
GLOBALIZATION AND DIRTY INDUSTRIES: DO POLLUTION HAVENS MATTER?
}

\author{
Jean-Marie Grether \\ Jaime de Melo \\ Working Paper 9776 \\ http://www.nber.org/papers/w9776

\section{NATIONAL BUREAU OF ECONOMIC RESEARCH 1050 Massachusetts Avenue Cambridge, MA 02138} \\ June 2003
}

Chapter forthcoming in "Challenges ot Globalization". An earlier version of this paper was presented at the CEPR/NBER/SNS International Seminar on International Trade "Challenges to Globalization", Stockholm, 24/25 May 2002. We thank Céline Carrère for data and much appreciated support, Nicole Mathys for excellent research assistance, Robert Baldwin for many helpful suggestions, and conference participants for useful comments. The views expressed herein are those of the authors and not necessarily those of the National Bureau of Economic Research.

C2003 by Jean-Marie Grether and Jaime de Melo. All rights reserved. Short sections of text not to exceed two paragraphs, may be quoted without explicit permission provided that full credit including (C) notice, is given to the source. 
Globalization and Dirty Industries: Do Pollution Havens Matter?

Jean-Marie Grether and Jaime de Melo

NBER Working Paper No. 9776

June 2003

JEL No. F18, Q28

\section{$\underline{\text { ABSTRACT }}$}

This paper reviews arguments and evidence on the impact of globalization on the environment, then presents evidence on production and international trade flows in five heavily polluting industries for 52 countries over the period 1981-98. A new decomposition of revealed comparative advantage (RCA) according to geographical origin reveals a delocalization to the South for all heavily polluting industries except non-ferrous metals that exhibits South-North delocalization in accordance with factor-abundance driven response to a reduction in trade barriers. Panel estimation of a gravity model of bilateral trade on the same data set reveals that, on average, polluting industries have higher barriers-to-trade costs (except non-ferrous metals with significantly lower barriers to trade) and little evidence of delocalization in response to a North-South regulatory gap.

Jean-Marie Grether

Groupe d'économie politique

7 Rue Pierre-à-Mazel

Université de Neuchâtel

CH-2000 Neuchâtel

Siwtzerland

jean-marie.grether@unine.ch
Jaime de Melo

Département d'économie politique

40, boulevard du Pont-d'Arve

Université de Genève

CH-1211 Genève 4

Switzerland

jaime.demelo@ecopo.unige.ch 


\section{Introduction}

In the debate on globalization and the environment, there is concern that the erasing of national borders through reduced barriers to trade will lead to competition for investment and jobs, resulting in a worldwide degradation of environmental standards (the 'race to the bottom' effect) and /or in a delocalization of heavy polluting industries in countries with lower standards (the 'pollution havens' effect). Moreover, environmentalists and ecologically-oriented academics argue that the political economy of decision-making is stacked up against the environment. In the North, OECD interest groups that support protectionist measures for other reasons continue to invoke the race-to-the-bottom model, relying on the perception that the regulatory gap automatically implies a race to the bottom, even though some have argued that countries may circumvent international agreements on tariffs by choosing strategic levels of domestic regulation. Because avoidance of a race to the bottom would call for the enforcement of uniform environmental standards in all countries, which cannot be created, they argue for trade restrictions until the regulatory gap is closed. In the South, corruption is likely to result in poor enforcement of the regulatory framework. Finally, at the international level, environmental activists fear that the dispute settlement mechanism of the WTO favors trade interests over environmental protection.

To sum up, the arguments raised above, as well as empirical evidence reviewed below, suggest that trade liberalization and globalization (in the form of reduced transaction costs) could lead to a global increase in environmental pollution as well as to an increase in resource depletion as natural resource exploiting industries, from forest logging companies to mining, 
relocate to places with less strict standards or use the threat of relocation to prevent the imposition of stricter standards. These effects are likely to be more important the further is environmental policy from the optimum and the less well-defined are property rights as is the case for the so-called 'global commons'. It is therefore not surprising that, even if trade liberalization and globalization more generally can lead to both an overall increase in welfare (especially if environmental policy is not too far from the optimum) and to a deterioration in environmental quality, a fundamental clash will persist between free trade proponents and environmentalists.

This paper addresses the relation between globalization and the environment by re-examining evidence of a North-South delocalization of heavily polluting industries. ${ }^{1}$ Section 2 reviews the evidence on 'pollution havens'", arguing that it is either too detailed (firm-specific of emission-specific evidence) or too fragmentary (case studies) to give a broad appreciation of the extent of delocalization over the past twenty years. The following sections then turn to new evidence based on 3-digit ISIC production and trade data for 52 countries over the period $1981-98 .{ }^{3}$ In section 3, we report on the worldwide evolution of heavy polluters (the so-called 'dirty' industries) and on the evolution of North-South revealed comparative advantage indexes. Section 4 then estimates a panel gravity trade model to examine patterns of trade in polluting products. Estimates reveal that transport

\footnotetext{
1 The causes of any detected relocation will not be identified because we are dealing with fairly aggregate data.

2 In the public debate, the 'pollution havens' effect refers either to an output reduction of polluting industries (and an increase in imports) in developed countries or to the relocation of industries abroad via FDI in response to a reduction in import protection or a regulatory gap.

3 The main data base has been elaborated by Nicita and Olarreaga (2001). An appendix to the paper describes data manipulation and the representativity of the sample in terms of global trade and production in polluting activities.
} 
costs may have acted as a brake on North-South relocation, and fail to detect a regulatory gap effect.

\section{Pollution Havens or pollution Halos?}

We review first the evidence on trade liberalization and patterns of trade in polluting industries based on multicountry studies that try to detect evidence of North-South delocalization. We then summarize results from single-country, often firm-level, studies that use more reliable environmental variables and are also generally better able to control for unobservable heterogeneity bias. We conclude with lessons from case studies and political-economy considerations.

\subsection{Evidence on production and trade in dirty products}

Evidence from aggregate production and trade data is based on a comparison between 'clean' and 'dirty' industries, the classification relying invariably on U.S. data, either on expenditure abatement costs, or on emissions of pollutants. ${ }^{4}$ Table 1 summarizes the results from these studies. Overall, the studies, which for the most part use the same definition of dirty industries as we do ${ }^{5}$, usually find mild support for the pollution havens hypothesis.

\footnotetext{
4 Most work on the US is based on pollution abatement capital expenditures or on pollution abatement costs (See e.g. Levinson and Taylor (2002, table 1). It turns out that the alternative classification based on emissions (see Hettige et al. 1995) produces a similar ranking for the cleanest and dirtiest industries (5 of the top 6 pollution industries are the same in both classifications).

5 As in this paper, polluting industries were classified on the basis of the comprehensive index of emissions per unit of output described in Hettige et al. (1995). That index includes conventional air, water and heavy metals pollutants. As to the applicability of that index based on US data to developing countries, Hettige et al. conclude (p. 2) that, even though pollution intensity is likely to be higher, "the pattern of sectoral rankings may be similar".
} 
Insert table 1 here:

Multi-country papers on trade and environmental costs

The large number of countries and the industrial-level approach gives breadth of scope to the studies described in table 1 , but at a cost. First changing patterns of production and trade could be due to omitted variables and unobserved heterogeneity that cannot be easily controlled for in large samples where aggregated data say very little about industry choices which would shed light on firms or production stages (Zarsky $(1999, \mathrm{p}$ 66)). For example, as pointed out by Mani and Wheeler in their case study of Japan, changes in local factor costs (price of energy, price of land) and changes in policies other than the stringency of environmental regulations could account for observed changes in trade patterns. Second, these studies give no evidence on investment patterns, and how these might react to changes in environmental regulation, which is at the heart of the 'pollution havens' debate. ${ }^{6}$ It is therefore not totally surprising that the papers surveyed in Dean (1992) and Zarsky (1999), by and large, fail to detect a significant correlation between the location decision of multinationals and the environmental standards of host countries. This suggests that, after all, when one goes beyond aggregate industry data, the "pollution havens" hypothesis may be a popular myth.

Recent studies respond to the criticism that the evidence so far does not address the research needs because of excessive

\footnotetext{
6 Smarzynska and Wei (2001) cite the following extract from "A Fair Trade Bill of Rights" proposed by the Sierra Club: "in our global economy, corporations move operations freely around the world, escaping tough control laws, labor standards, and even the taxes that pay for social and environmental needs".
} 
aggregation. However, this recent evidence, summarized below, is still very partial, and heavily focussed on the US.

\subsection{Evidence on the location of dirty industries}

Levinson and Taylor (2002) revisit the single-equation model of Grossman-Krueger (1993) using panel data for US imports in a two-equation model in which abatement costs are a function of exogenous industry characteristics while imports are a function of abatement costs. Contrary to previous estimates, they find support for the pollution havens hypothesis: industries whose abatement costs increased the most, saw the largest relative increase in imports from Mexico, Canada, Latin American and the rest-of-the-world. ${ }^{7}$

Drawing on environmental costs across the US that are more comparable than the rough indices that must be used in crosscountry work, Keller and Levinson (2001) analyze inward FDI into the US over the period 1977-94. They find robust evidence that relative (across states) abatement costs had moderate deterrent effects on foreign investment.

Others have analyzed outward FDI to developing countries. Eskeland and Harrison (2002), examine inward FDI in Mexico, Morocco, Venezuela and Côte d'Ivoire at the four-digit level using US abatement cost data controlling for country-specific factors. They find weak evidence of some FDI being attracted to sectors with high levels of air pollution, but no evidence of FDI to avoid abatement costs. They also find that foreign firms are more fuel-efficient in that they use less 'dirty fuels'.

\footnotetext{
7 Ederington and Minier (2001) also revisit the Grossman-Krueger study, assuming that pollution regulation is also endogenous, but determined by political-economy motives. They also find support for the pollution-havens
} 
This evidence supports the 'pollution halo' hypothesis: superior technology and management, coupled with demands by "green" consumers in the OECD, lift industry standards overall. ${ }^{8}$

Smarzynska and Wei (2001), estimate a probit of FDI of 534 multinationals in 24 transition economies during the period 1989-94 as a function of host country characteristics. These include a transformed (to avoid outlier dominance) US-based index of dirtiness of the firm at the 4-digit level, an index of the laxity of host country's environmental standards captured by a corruption index, and several measures of environmental standards (participation in international treaties, quality of air and water standards, observed reductions in various pollutants). In spite of this careful attempt at unveiling a 'pollution haven' effect, they conclude that host-country environmental standards (after controlling for other country characteristics including corruption) had very little impact on FDI inflows.

\subsection{Case studies and political-economy considerations}

Reviewing recently available data, Wheeler (2000) shows that suspended particulate matter release (the most dangerous form of air pollution) has been declining rapidly in Brazil, China, Mexico, fast growing countries in the era of globalization and big recipients of FDI. Organic water pollution is also found to fall drastically as income per capita rises (poorest countries have approximately tenfold differential pollution intensity). ${ }^{9}$

hypothesis, this time because inefficient industries seek protection via environmental legislation.

8 The mixed evidence on the pollution halo hypothesis is reviewed in Zarsky (1999) .

9 These results accord with independent estimates of environmental performance constructed by Dasgupta et al. (1996) from a responses to a 
In addition to the standard explanations (pollution control is not a critical cost factor for firms, large multinationals adhere to OECD standards), he also points out that case studies show that low-income communities often penalize dangerous polluters even when formal regulation is absent or weak. Wheeler concludes that the "bottom" rises with economic growth.

This result is reinforced by recent evidence based on a political-economy approach that endogenizes corruption in the decision-making process. Assuming that governments' accept bribes in formulation of their regulatory policies, Damia et al (2000) find support in panel data for 30 countries over the period 1982-92 that the level of environmental stringency is negatively correlated with an index of corruption and positively with an index of trade openness. Given that corruption is typically higher in low-income countries, this corroborates the earlier finding mentioned above, that environmental stringency increases rapidly with income.

\section{Shifting patterns of production and comparative advantage in polluting industries}

Direct approaches to the measurement of pollution emission (e.g. Grossman and Krueger (1995), Dean (2000), Antweiler, Copeland and Taylor (2001) and several of the studies mentioned above) use emission estimates at geographical sites of pollutant particles (sulfur dioxide is a favorite) or the release of pollutants in several media (air, water, etc...). That approach has several advantages: emissions are directly measured at each site, and it is not assumed that pollutant intensity is the same across countries. On the other hand

detailed questionnaire administered to 145 countries (they find a correlation of about 0.8 between their measure of environment performance 
activity (e.g. production levels) is not measured directly. Arguably, this is a shortcoming if one is interested in the pollution haven hypothesis. Indeed, emissions could be high for other reasons than the relocation of firms to countries with low standards (China's use of coal as an energy source is largely independent of the existence of pollution havens).

The alternative chosen here is to use an approach in which emission intensity is not measured directly. We adopt the approach in the studies summarized in table 1 where dirty industries are classified according to an index of emission intensity in the air, water and heavy metals in the US described in footnote 4. We selected the same five most polluting industries in the US in (1987) selected by Mani and Wheeler (1999) (three-digit ISIC code in parenthesis): Iron and Steel (371); Non-ferrous metals (372); Industrial chemicals (351); Non-metallic mineral products (369); pulp and paper (341). ${ }^{10}$ According to Mani and Wheeler (1998), compared to the five cleanest U.S. manufacturing activities (textiles (ISIC 321), Non-electric machinery (382), Electric machinery (383), transport equipment (384), instruments (385), the dirtiest have the following characteristics: 40\% less labor-intensive; capital-output ratio twice as high; and an energy-intensity ratio three times as high.

\subsection{Shifting patterns of production}

We start with examination of the broad data for our sample of 52 countries over the period 1981-98. The sample (years and countries) is the largest for which we could obtain production data matching trade data at the 3-digit ISIC level. Compared to

or environment policy and income per capita). 
the earlier studies mentioned in table 1, this sample has production data for a larger group of countries, though at a cost because comprehensive data--only available since 1981-implies that we are missing some of the early years of environmental regulation in OECD countries in the seventies.

Because there is a close correlation between the stringency of environmental regulation and income per capita, we start with histograms of indices of pollution intensity ranked by income per capita quintile (the data are three-year averages at the beginning and end of period). Given our sample size, each quintile has 10 or 11 observations.

Insert Figure 1 here:

Histograms of production and consumption shares of polluting products

Figure 1 reveals a slight change in the middle of the distribution of production and consumption of dirty industries as the second richest quintile sees a reduction in production and consumption shares in favor of the top and lowest quintiles. Turning to export and import shares (figure 2), one notices a reduction in both trade shares of the highest quintile in favor of the remaining quintiles.

These aggregate figures mask compositional shifts apparent from inspection of the histograms at the industry level (see figure A3.1 in the Appendix). For the second richest quintile, the output share is always decreasing, but changes in the export share vary a lot across sectors. For the richest quintile, the

10 Mani and Wheeler (1999, table 1) describes the intensity of pollutants emission in water, air and heavy metals. 
output share is decreasing except for paper and products (ISIC 341) and other non-metallic mineral products (369), while the export share is always decreasing, except for non-ferrous metals (372).

Insert Figure 2 here:

Histograms of export and import shares of polluting products

In sum, these broad figures suggest some delocalization of pollution industries to poorer economies. However, aggregate effects are weak, partly because of opposite patterns at the sector level.

\subsection{Shifting patterns of revealed comparative advantage}

We look next for further evidence of changes in trade patterns in dirty industries. We report on revealed comparative advantage (RCA) indices computed at the beginning or at the end of the sample period. RCA indices are not measures of comparative advantage since they also incorporate the effects of changes in the policy environment (trade policy, regulatory environment, etc).

The RCA index for country $i$ and product $p$ is given by:

$$
\mathrm{RCA}_{i}^{p}=\frac{S_{w p}^{i p}}{S_{w a}^{i a}}=\frac{S_{i a}^{i p}}{S_{w a}^{w p}}
$$

where $S_{w p}^{i p}\left(S_{w a}^{i a}\right)$ is country i's share in world exports of polluting products (of all products) and $S_{i a}^{i p}\left(S_{w a}^{w p}\right)$ is the share 
of polluting products in total exports of country $i$ (of the world).

Countries are split into two income groups (see table A1 in the Appendix) that replicate the distinction between the three poorest and two richest quintiles of the previous section: 22 high income countries (1991 GNP per capita larger than 7910 USD according to the World Bank) and 30 low and middle-income countries. Hereafter the former group is designed by developed countries (DCs) or "North", the latter by less developed countries (LDCs) or "South".

A first glimpse at the aggregate figures (see table 2) confirms that LDCs' share in world trade of polluting products is on the rise. But the average annual rate of growth is lower for polluting products than for exports in general. As a result, LDCs as a whole exhibit a decreasing RCA (and an increasing revealed comparative disadvantage) in polluting products (see last columns of table 2).

Insert table 2 here:

Share of developing countries in world trade

However, inspection at the industry level (see table A2.1, reveals that this reverse-delocalization outcome is due to the dominating effect of non-ferrous metals (ISIC 372). All other four industries present some ingredient of delocalization, with a particularly strong increase in RCA for industrial chemicals (351). Interestingly, non-ferrous metals represented more than $40 \%$ of LDCs exports at the beginning and less than 25\% at the end of the period, while the pattern is exactly opposite for industrial chemicals. 
To unveil cross-country variations, figure 3 ranks countries by decreasing order of RCAs for both income groups. In each case, the dashed line represents the end-of-period pattern with countries ranked by decreasing order of comparative advantage so that all observations above (below) unity correspond to countries with a a revealed comparative advantage (disadvantage). A shift to the right (left) implies increasing (decreasing) revealed comparative advantage, and a flattening of the curve, a less pronounced pattern of specialization.

Figure 3:

Revealed comparative advantage indices in polluting products

Overall, LDCs' pattern of RCAs is characterized by higher upper values of RCAs and a steeper curve than high-income countries. Over time, both curves appear to shift right ${ }^{11}$ and become somewhat flatter. The increase in RCAs seems larger in LDCs, where it is concentrated in the middle of the distribution, while it basically affects the end of the distribution in the other income group. At the industry level (see figure A3.2) results for LDCs are quite similar, expect for non-ferrous metals, where the RCA curve shifts in ${ }^{12}$.

Still, the above pattern does not say anything about the changing pattern of RCAs between the North and the South, which is what the delocalization hypothesis is about. To measure this

11 This result may seem puzzling but the contradiction is only apparent: the weighted sum of RCAs is indeed equal to 1.0, but the weights can vary. Thus, a simultaneous increase in all RCA indices may well happen, provided a larger weight is put on smaller values.

12 Note that the pattern illustrated by figure 3 only reflects a "structural" effect, i.e. the change of individual RCAs. The evolution of the aggregate RCA for LDCs as a group is also governed by a "composition" effect, namely the impact of changes in countries' shares keeping RCA indices constant. Straightforward calculations reveal that for LDCs the composition effect $(-0.19)$ has been stronger than the structural effect (0.13), leading to a net decrease of the aggregate RCA reported in table 2 (for results at the industry level, see table A2.2). 
effect, we introduce a new decomposition that isolates the impact of geography on the RCA index. From (1), note that the RCA of country $i$ in product $p\left(R^{\prime} A_{i}^{p}\right)$ can be decomposed into:

$\operatorname{RCA}_{i}^{\mathrm{p}}=\sum_{j=1}^{\mathrm{N}} \mathrm{RCA}_{i j}^{\mathrm{p}} \mathrm{S}_{i w a}^{i j a}$

where the bilateral RCA $\left(R_{C A} A_{i j}^{p}\right)$ is defined as the ratio between the share of product $p$ in all exports of country $i$ to country $j$ $\left(S_{i j a}^{i j p}\right)$ and the share of product $p$ in total world exports $\left(S_{w a}^{w p}\right)$. This share is weighted by the share of country $j$ in total exports country $i$ to the world $\left(S_{i w a}^{i j a}\right)$.

Now let the world be divided in two groups of countries: $\mathrm{n}_{\mathrm{S}}$ in the South, $n_{N}$ in the North $\left(n_{S}+n_{N}=N\right)$. Then (2) can be rewritten:

$R C A_{i}^{p}=S_{i}^{p}+N_{i}^{p} \equiv \sum_{j=1}^{n_{S}} R C A_{i j}^{p} S_{i w a}^{i j a}+\sum_{j=1}^{n_{N}} R C A_{i j}^{p} S_{i w a}^{i j a}$

where $S_{i}^{p}$ is the South's contribution and $N_{i}^{p}$ the North's contribution to $\mathrm{RCA}_{i}^{\mathrm{p}}$. Thus, in terms of variation between the end (96-98) and the beginning (81-83) of the sample period, one obtains:

$\Delta \mathrm{RCA}_{i}^{\mathrm{p}}=\Delta \mathrm{S}_{i}^{\mathrm{p}}+\Delta \mathrm{N}_{i}^{\mathrm{p}}$

Results from applying this decomposition to the two groups of countries are reported in table 3. For each polluting sector, we report the (unweighted) average of both sides of equation 
(4) over the LDCs' group. It appears that in all cases but one, the North's contribution to the change in LDCs' RCA is positive. This result is consistent with the pollution haven effect. Again, the only exception is non-ferrous metal, where North-South trade has negatively contributed to the RCA of the South.

Insert table 3 here:

Table 3: North-South bilateral RCAs for polluting products

In sum, the RCA-based evidence on delocalization of polluting activities towards the South is rather mixed. As a group, developing countries exhibit a surprising reversedelocalization pattern of increasing revealed comparative disadvantage in polluting products. However, as shown above, this reflects both the pattern of one particular industry (nonferrous metals) and a composition effect: within the group of developing countries, those less prone to export polluting products have gained ground. In fact, most developing countries have in fact experienced an increase in their RCA in polluting products. Moreover, after controlling for geography, it turns out that for all but for one case (non-ferrous metals), NorthSouth trade has had a positive impact on LDCs' comparative advantage in these products.

\section{Bilateral trade patterns in polluting products}

Dirty industries are typically weight-reducing industries. They are also intermediate-goods producing industries. As a result if they move to the South, then transport costs must be incurred if the final (consumer goods) products are still produced in the North, as would be the case, for example in the 
newspaper printing industry. Hence the reduction in transport costs and protection that has occurred with globalization may not have had much effect on the location of these industries.

Our third piece of evidence consists of checking if, indeed, polluting industries are not likely to relocate so easily because of relatively high transport costs. To check whether this may be the case, we estimate a standard bilateral trade gravity model for polluting products, and compare the coefficients with those obtained for non-polluting manufactures.

Take the simplest justification for the gravity model: trade is balanced (in this case at the industry level which some would find unrealistic), and each country consumes its output, and that of other countries according to its share, $s_{i}$, in world GNP, $Y^{W}$. Then (see Rauch, 1999), bilateral trade between $i$ and $j$ will be given by: $M_{i j}=\left(2 Y_{i} Y_{j}\right) / Y^{W}=f\left(W_{i j}\right)$. The standard "generalized" gravity equation (which can be obtained from a variety of theories) can be written as: $M_{i j}=f\left(W_{i j}\right)\left(\theta_{i j}\right)^{-\sigma}$ where $\theta_{i j}$ is an index of barriers-to-trade between $i$ and $j, W_{i j}$ is a vector of other intervening variables that includes the bilateral exchange rate, $e_{i j}$, and prices, and $\sigma$ is an estimate of the ease of substitution across suppliers.

In the standard estimation of the gravity model, $\theta_{i j}$ is captured either by distance between partners, or if one is careful, by relative distance to an average distance among partners in the sample, $\overline{\mathrm{DIST}}$, i.e. by, $\mathrm{DT}_{i j}=\mathrm{DIST}_{i j} / \overline{\mathrm{DIST}}$. Dummy variables that control for characteristics that are specific to bilateral trade between $i$ and $j$ (e.g. a common border, BOR ij, landlockedness in either country, $\mathrm{LL}_{i}\left(\mathrm{LL}_{j}\right)$ ) are also 
introduced to capture the effects of barriers to trade. ${ }^{13}$ Here, we go beyond the standard formulation by also including an index of the quality of infrastructure in each country in period $t, I N F_{i t}\left(I N F_{j t}\right)$, higher values of the index corresponding to better quality of infrastructure. ${ }^{14}$ Finally, because we estimate the model in panel, we include the bilateral exchange rate, $R E R_{i j t}$, defined so that an increase in its value implies a real depreciation of i's currency.

The above considerations lead us to estimate in panel the following model (expected signs in parenthesis):

$$
\begin{aligned}
\operatorname{lnM}_{i j t}= & \alpha_{0}+\alpha_{t}+\alpha_{i j}+\alpha_{1} \operatorname{lnY}_{i t}+\alpha_{2} \operatorname{lnY}_{j t}+\alpha_{3} \operatorname{lnINF}_{i t}+ \\
& \alpha_{4} \operatorname{lnINF}_{j t}+\alpha_{5} \operatorname{lnRER}_{i j t}+\alpha_{6} \mathrm{BOR}_{i j}+\alpha_{7} \mathrm{LL}_{i}+\alpha_{8} \mathrm{LL}_{j}+ \\
& {\left[\alpha_{9} \operatorname{lnDY}_{i j t}\right]+\beta_{1} \operatorname{lnDT}_{i j}+\eta_{i j t} }
\end{aligned}
$$

$\left(\alpha_{1}>0, \alpha_{2}>0, \alpha_{3}>0, \alpha_{4}>0, \alpha_{5}<0 \alpha_{6}>0, \alpha_{7}<0, \alpha_{8}<0, \beta_{1}<0\right)$

In (5), $\alpha_{0}$ is an effect common to all years and pairs of countries (constant term), $\alpha_{t}$ an effect specific to year $t$ but common to all countries (e.g. changes in the price of oil), $\alpha_{i j}$ an effect specific to each pair of countries but common to all years and $\eta_{i j t}$ is the error term.

In a second specification we introduce the difference in GNP per capita $D Y_{i j}=\left[\left(Y_{i} / N_{i}\right)-\left(Y_{j} / N_{j}\right)\right]$ in the equation, this additional variable presumably capturing the effects of the

${ }^{13}$ Brun et al. (2002) argue that the standard barriers-to-trade function is mispecified and propose a more general formulation that captures both variables that include country-specific characteristics, and variables that capture time-dependent costs (e.g. the price of oil). Since here we are only interested in country-specific characteristics, time-dependent shocks are captured by time dummies.

${ }^{14}$ The index is itself a weighted sum of four indices computed each year: road density, paved roads, railway and the number of telephone lines per capita. 
regulatory gap across countries. If the regulatory gap effect is important, one would expect a positive sign for $\alpha_{9} .^{15}$

For estimation purposes, equation (5) can be rewritten as:

$\ln M_{i j t}=x_{i j t} \varphi+z_{i j} \delta+u_{i j t} \quad$ with $u_{i j t}=\mu_{i j}+v_{i j t}$

where X (Z) represents the vector of variables that vary over time (are time-invariant) and a random error-component is used because the within-transformation in a fixed-effects model removes the variables that are cross-sectional time invariant. To deal with the possibility of correlation between the explanatory variables and the specific effects, we use the instrument variable estimator proposed by Hausman and Taylor (1981). However, we also report fixed-effects estimates which correspond to the correct specification under the maintained hypothesis (columns 1 \& 2 of table 4).

Because the null hypothesis of correlation between explanatory variables and the error term cannot be rejected, we reestimated the random-effects model treating the GDP variables as endogenous. The results are reported in columns $3-6$ of table 4. Coefficient estimates are robust and, after instrumentation, the coefficient estimates are quite close in value to those obtained under the fixed-effects estimates.

Insert table 4 here:

Gravity model: panel estimates

First note that all coefficients have the expected signs and, as usual in gravity models with large samples, are robust to

15 In a full-fledged model with endogenous determination of environmental policy, Antweiler et al. (2001) obtain a reduced form in which the technique effect (change in environmental policy) is captured by changes in income per capita. 
changes in specification. ${ }^{16}$ Notably, the dummy variables for infrastructure have the expected signs and are highly significant. So is the real exchange rate variable which captures, at least partly, some of the effects of trade liberalization that would not have already been captured in the time dummy variables (not reported here). Income variables are also, as expected, highly significant. Overall then, except for the landlocked variables, which are at times insignificant, all coefficient estimates have expected signs and plausible values.

Compare now the results between the panel estimates for all manufactures --except polluting products-(column 5) with those for the five polluting industries (column 6). Note first that the estimated coefficient for distance is a third higher for the group of polluting industries compared to the rest of manufacturing. ${ }^{17}$ Second, note that the proxy for the regulatory gap captured by the log difference of per capita GNPs is negative for non-polluting manufactures (as one would expect from the trade theory literature under imperfect competition where trade flows are an increasing function of the similarity in income per capita) while it is insignificant (though positive) for polluting industries. Now, if indeed the regulatory gap can be approximated by differences in per capita GDPs across partners, the presence of pollution havens would be reflected in a significant positive coefficient for this variable.

Compositional effects for the coefficients of interest are shown in table 5. Non-ferrous metals (and to a lesser extent iron \& steel) stand out with low elasticity estimates for

\footnotetext{
${ }^{16}$ We also experimented with other variants (not reported here) by including population variables and obtained virtually identical estimates for the included variables.
} 
distance. If one were to take seriously cross-sector

differences in magnitude, one would argue that the South-North 'reverse' (in the sense of the pollution havens hypothesis) delocalization of non-ferrous metals according to comparative advantage in response to the reduction in protection would have occurred because of fewer natural barriers to trade. Of course, there are other factors as well to explain the developments in these sectors, including the heavy protection of these industries in the North.

Insert table 5 here:

Panel estimates by industry

The sectoral pattern of estimates for $\alpha_{9}$ indicates that the regulatory gap would have had an effect on bilateral trade patterns for two sectors: non-metallic minerals and iron \& steel, and marginally for the pulp \& paper industry. Again, the non-ferrous metals stands out, suggesting no effect of differences in the regulatory environment, once other intervening factors are controlled for.

In sum, the pattern of trade elasticities to transport costs obtained here makes sense. Most heavy polluting sectors are intermediate goods, so proximity to users should enter into location decisions more heavily than customs goods that are typically high-value, low-weight industries that can be shipped by airfreight. Interestingly, after controlling for a number of factors that influence the volume of bilateral trade, we find little evidence of the presence of a regulatory gap, thus broadly supporting (indirectly) the 'pollution halo' hypothesis.

17 One could note that the coefficient estimates on infrastructure are much higher for these weight reducing activities which is also a plausible 


\section{Conclusions}

Concerns that polluting industries would 'go South' was first raised in the late eighties at the time when labor intensive activities like the garment industries were moving South in response to falling barriers to trade worldwide. Such delocalization could be characterized as a continuous search for 'low-wage havens' by apparel manufacturers in an industry that has remained labor-intensive. Fears about pollution havens were already expressed at the time notably because of the possible impact of the regulatory gap between OECD economies where polluters paying more would lead them to search for 'pollution havens' analogous to 'low-wage havens'. Later with the globalization debate, the hypothesis gained new momentum by those who have read into globalization a breakdown of national borders, making it difficult to control location choices by multinationals.

This paper started with a review of the now substantial evidence surrounding this debate which can be classified in three rather distinct families. First, aggregate comparisons of output and trade trends based on a classification of pollution industries based on US emissions revealed very marginal delocalization to the South. Second, firm-level estimates of FDI location choices by-and-large found at best marginal evidence either of location choice in the US in response to cross-State differences in environmental regulations, or of location choices by multinational firms across developing countries in response to differences in environmental regulations. Reasons for this lack of response to the so-called regulatory gap were found in the third piece of evidence largely assembled from developing-country case studies. Taking into account political economy determinants of multinational

result signifying another brake on North-South delocalization. 
behavior in host countries and the internal trade-offs between leveling up emission standards (to avoid dealing with multiple technologies) and cutting abatement expenditures, overall this literature finds no evidence of havens, but rather of 'halos'.

Turning to new evidence, this paper drew on a large sample of countries accounting for the bulk of worldwide production and trade in polluting products over the period 1980-98. Globally, we found that revealed comparative advantage (RCA) in polluting products by LDCs fell as one would expect if the environment is indeed a normal good in consumption. At the same time, however, the decomposition indicates that the period witnessed a trend towards relocation of all (but one) polluting industries to the South. The exception was the reverse delocalization detected for non-ferrous metals. We argued that this reverse delocalization was as one would expect according to a comparative advantage driven response to trade liberalization in a sector where barriers-to-trade turn out to be relatively small. Finally, in the aggregate, RCA decompositions revealed no evidence of trade flows being significantly driven by the regulatory gap, again with the exception of some positive evidence for the non-metallic and iron \& steel sectors.

Estimates from a panel gravity model fitted to the same industries showed that, in comparison with other industries, polluting industries had higher barriers-to-trade in the form of larger elasticities of bilateral trade with respect to transport costs. These results confirm the intuition that most heavy polluters are both weight-reducing industries and intermediates for which proximity to users should enter location decisions more heavily than for customs goods (i.e. differentiated products) that are typically high-value products. Finally after controlling for several factors that 
influence the volume of bilateral trade, we find little evidence of the presence of a regulatory gap.

In sum, the paper provided some support for the 'pollution havens' hypothesis, a result in line with several earlier studies reviewed here. Beyond this result, the paper contributed to the debate by identifying a new explanation for the less-than-expected delocalization that had not been identified, nor quantified, in the literature: relatively high natural barriers-to-trade in the typical heavy polluting industries.

In concluding, one should however keep in mind two important caveats with respect to the 'pollution havens' debate. First, like the rest of the literature reviewed in the paper, we only examined manufactures. This implies that we did not take into account resource-extracting industries that may have successively sought pollution havens. Second, even within the narrow confines of trade pattern quantification, a fuller evaluation of the debate on trade, globalization and the environment, would also have to examine the direct and indirect energy content of trade. 


\section{Bibliography}

Antweiler, A, B. Copeland and M. Taylor (2001), Is Free Trade Good for the Environment?", American Economic Review, 91, 877908 .

Beers, Van, and Bergh, Van den (1997), "An Empirical Multicountry Analysis of the Impact of Environmental Regulations on Foreign Trade Flows", Kyklos, 50, 29-46.

Brun, J.F., C. Carrère, P. Guillaumont, and J. de Melo (2002), "Has Distance Died? Evidence from a Panel Gravity Model", mimeo CERDI.

Copeland, B., and S. Taylor (1994), "North-South Trade and the Global Environment", Quarterly Journal of Economics, 109, 75587.

Copeland, B. and S. Taylor (2001), "International Trade and the Environment: A Framework for Analysis", NBER \# 8540

Damia, R. P. Fredriksson and J. List (2000), Trade Liberalization, Corruption, and Environmental Policy Formation: Theory and Evidence", CIES DP \#0047, Adelaide University, Australia

Dasgupta, S, A. Mody, S. Roy and D. Wheeler (1996), "Environmental Regulation and Development: A Cross-Country Empirical Analysis", WBPR\# 1448.

Dean, J. (1992), "Trade and the Environment: A Survey of the Literature", in P. Low ed.

Dean, J. (1998), "Testing the Impact of Trade Liberalization on the Environment: Theory and Evidence", chp4. in Fredriksson, ed.

Ederington, J. and J. Minier (2001), "Is Environmental Policy a Secondary Trade Barrier? An Empirical Analyis", mimeo, University of Miami.

Eskeland, G. and A. Harrison (2002), "Moving to Greener Pastures? Multinationals and the Pollution Havens Hypothesis", \#NBER

Fredriksson, P. ed. (1999), Trade, Global Policy, and the Environment, WBDP \#402, World Bank, Washington, D.C.

Grether, J.M. and J de Melo (1996), "Commerce, Environnement et Relations Nord-Sud: les enjeux et quelques tendances récentes" Revue d'économie du développement, vol.4, 69-102 
Grossman G.M. and A.B. Krueger (1993), "Environmental Impacts of a North American Free Trade Agreement", in P.M. Graber, ed., The U.S.-Mexico free trade agreement, Cambridge, MIT Press, 1356 .

Hausman, A. and E. Taylor (1981), "Panel Data and Unobservable Individual Effects", Econometrica, 49, 119-135.

Hettige, Martin, Singh and Wheeler (1995), " IPPS: The Industrial Projection System", WPS\# 1431, The World Bank, Washington, D.C.

Hettige, H., R.E.B. Lucas and D. Wheeler (1992), "The Toxic Instensity of Industrial Production: Global Patterns, Trends and Trade Policy", American Economic Review 82: 478-81.

Keller, W., and A. Levinson (forthcoming), "Pollution Abatement Costs and Foreign Direct Investment Inflows to the US", Review of Economics and Statistics,

Levinson, A. and S. Taylor (2002), "Trade and the Environment: Unmasking the Pollution Haven Effect", mimeo, Georgetown U.

Low, P. and A. Yeats (1992), "Do Dirty Industries Migrate?", in P. Low (ed.), International Trade and the Environment, World Bank Discussion paper \#159.

Mani, M. and D. Wheeler, (1999), "In Search of Pollution Havens? Dirty Industry in the World Economy, 1960-95", in Fredriksson (ed).

Neumayer, E. 2000, "Trade and the Environment: A critical assessment and some suggestions for reconciliation", Environment and Natural Resources

Nicita, A. and M. Olarreaga (2001), "Trade and Production, 1976-1999", mimeo accompanying the Trade an Production Database, the World Bank.

Smarzynska, B. and S-J Wei (2001), " Pollution Havens and Foreign Direct Investment: dirty secret or popular myth?", NBER \# 8465

Tobey, J. (1990), "The Effects of Domestic Environmental Policies on Patterns of World Trade: an Empirical Test", Kyklos, 43,2, 191-201

Zarsky, L. (1999), "Havens, halos and spaghetti: untangling the evidence about Foreign Direct Investment and the Environment", mimeo, OECD, Paris. 


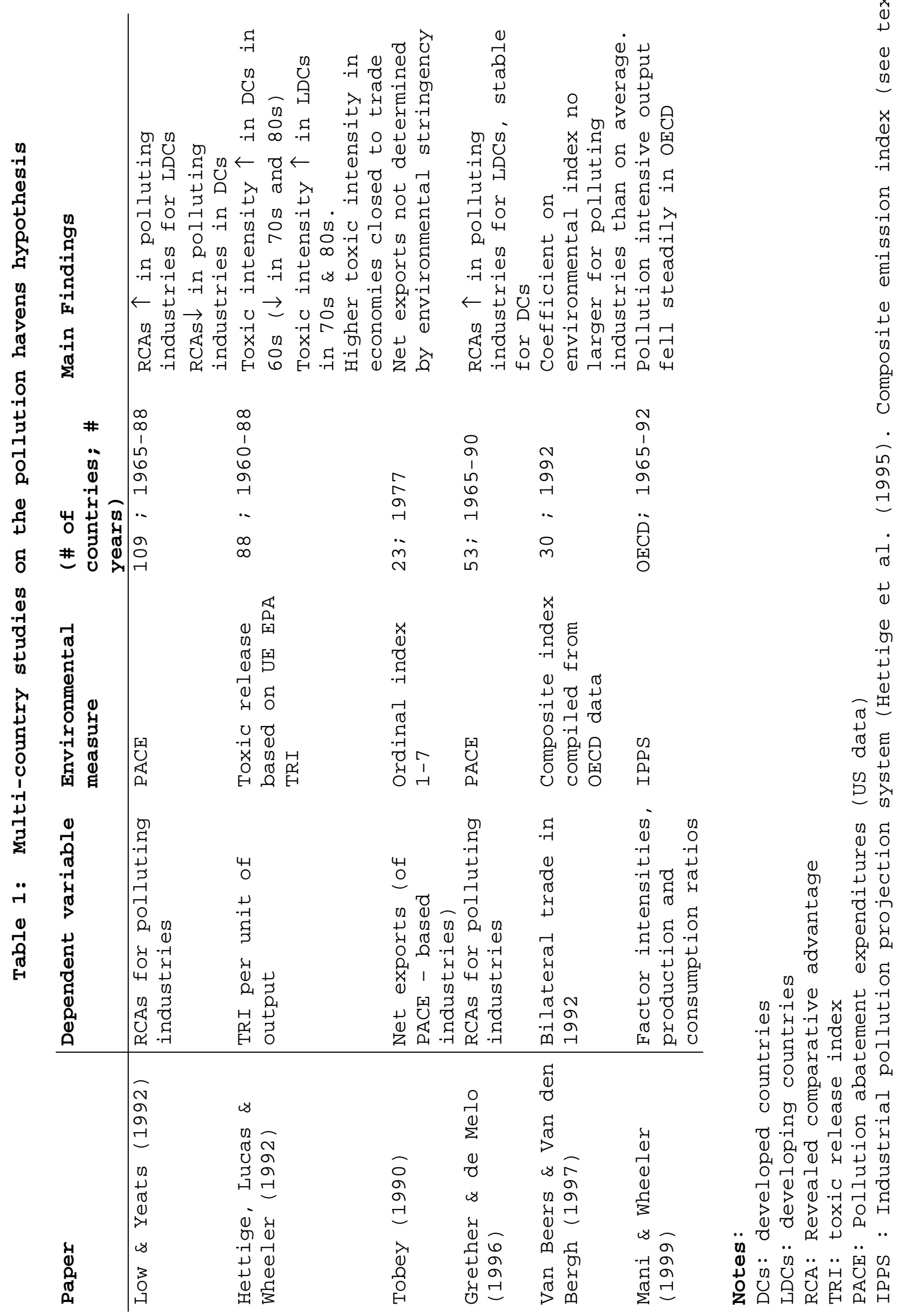




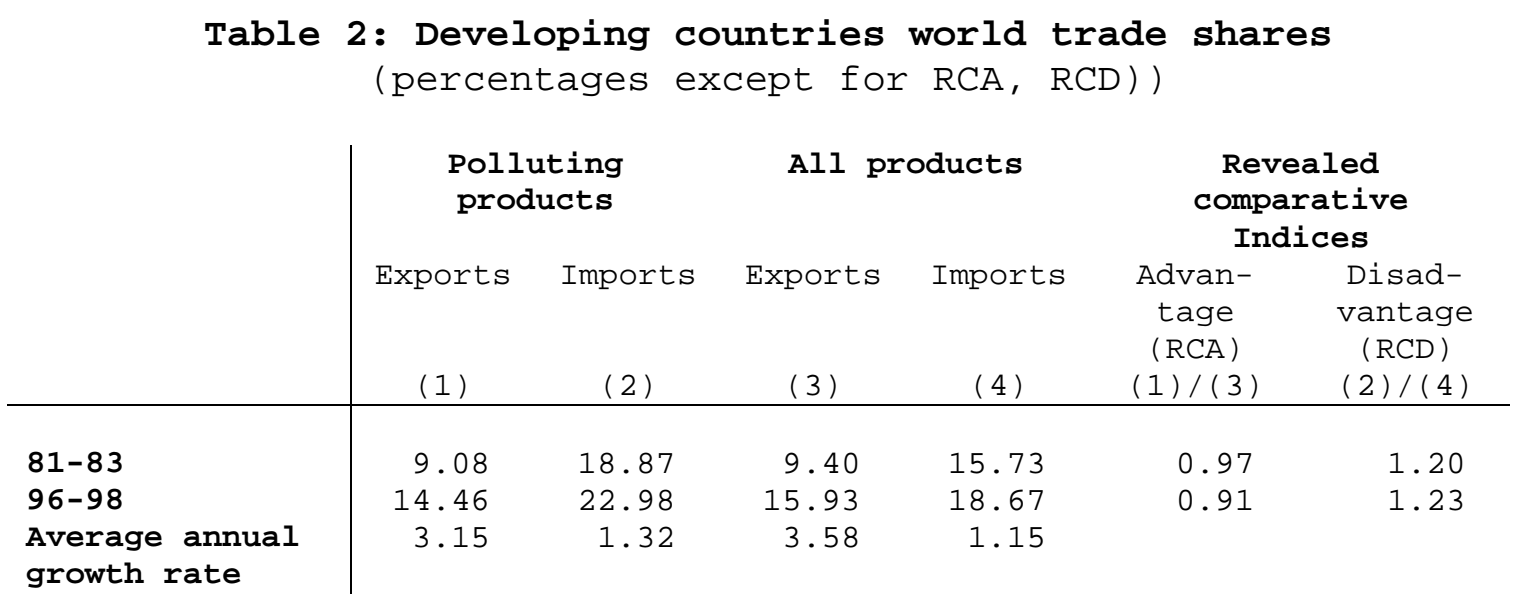

Table 3: North-South bilateral RCAs for polluting products*

\begin{tabular}{lcc}
$\begin{array}{l}\text { Sector } \\
\Delta \mathbf{S}\end{array}$ & $\Delta \mathbf{R C A}$ & $\Delta \mathbf{N}$ \\
\hline $\begin{array}{l}\text { Pulp \& paper (341) } \\
0.13\end{array}$ & 0.23 & 0.10 \\
Ind. Chemicals (351) & 0.41 & 0.21 \\
0.20 & & \\
Non-metallic minerals (369) & 0.38 & 0.61 \\
0.22 & 0.66 & 0.39 \\
Iron \& Steel (371) & & \\
0.27 & -0.57 & -0.79 \\
Non-ferrous metals (372) & & \\
0.22 & &
\end{tabular}

* Computed from equation (6) 


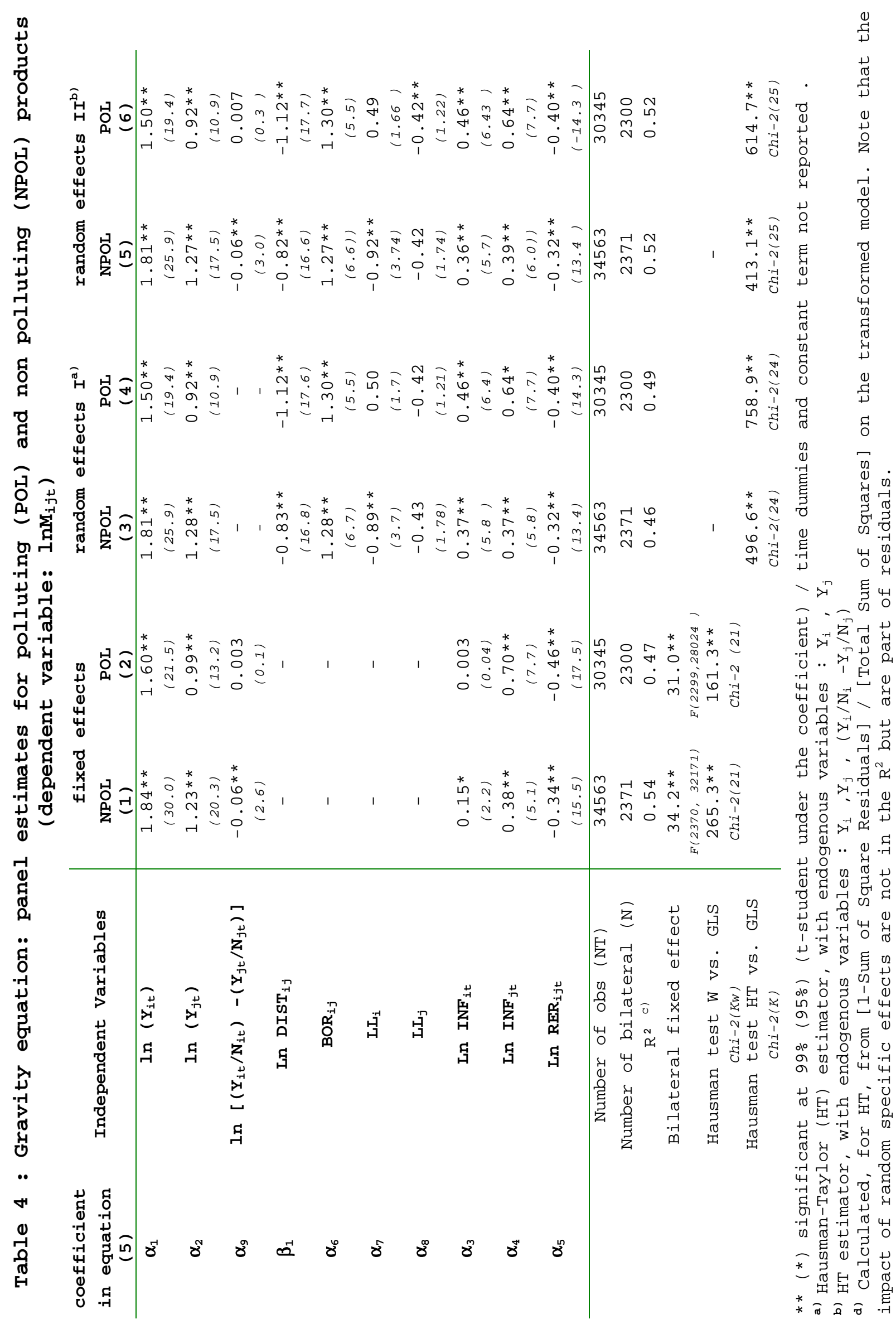


Table 5 : Panel estimates by industry

\begin{tabular}{|c|c|c|}
\hline \multirow{2}{*}{ Industries } & \multicolumn{2}{|c|}{ Equation (9) } \\
\hline & $\beta_{1}$ & $\alpha_{9}$ \\
\hline Non-polluting & $-0.82 \star \star$ & $-0.06 * \star$ \\
\hline All polluting & $-1 \cdot 12 \star \star$ & 0.007 \\
\hline Pulp and paper * & $-1.40 * \star$ & $0.08 *$ \\
\hline Industrial Chemicals & $-1.23 * \star$ & 0.03 \\
\hline Non-metallic minerals & $-1.21 \star \star$ & $0.12 * \star$ \\
\hline Iron \& Steel & $-1 \cdot 12 \star \star$ & $0.11 \star \star$ \\
\hline Non-Ferrous Metals & $-0.95 * \star$ & -0.04 \\
\hline
\end{tabular}

** and * significant at $99 \%$ and $95 \%$ respectively

* An estimate of -1.40 [-0.95] implies that if trade flows are normalized to 1 for a distance of $1000 \mathrm{~km}$, a doubling of distance to 2000 would reduce bilateral trade volume to 0.38 [0.52]. 


\section{Figure 1: Histograms of output and consumption shares of polluting products}

(a) : Output

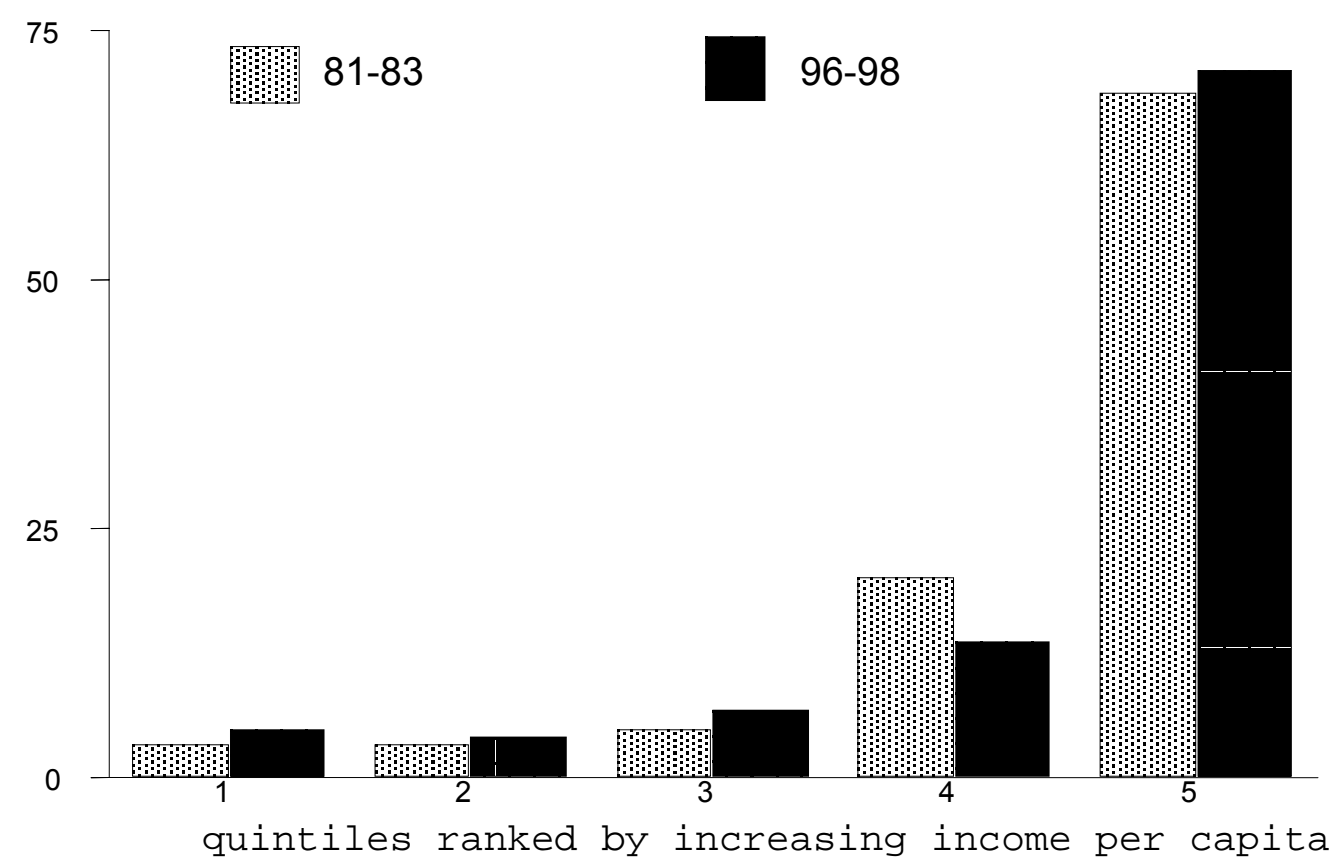

(b) : Consumption

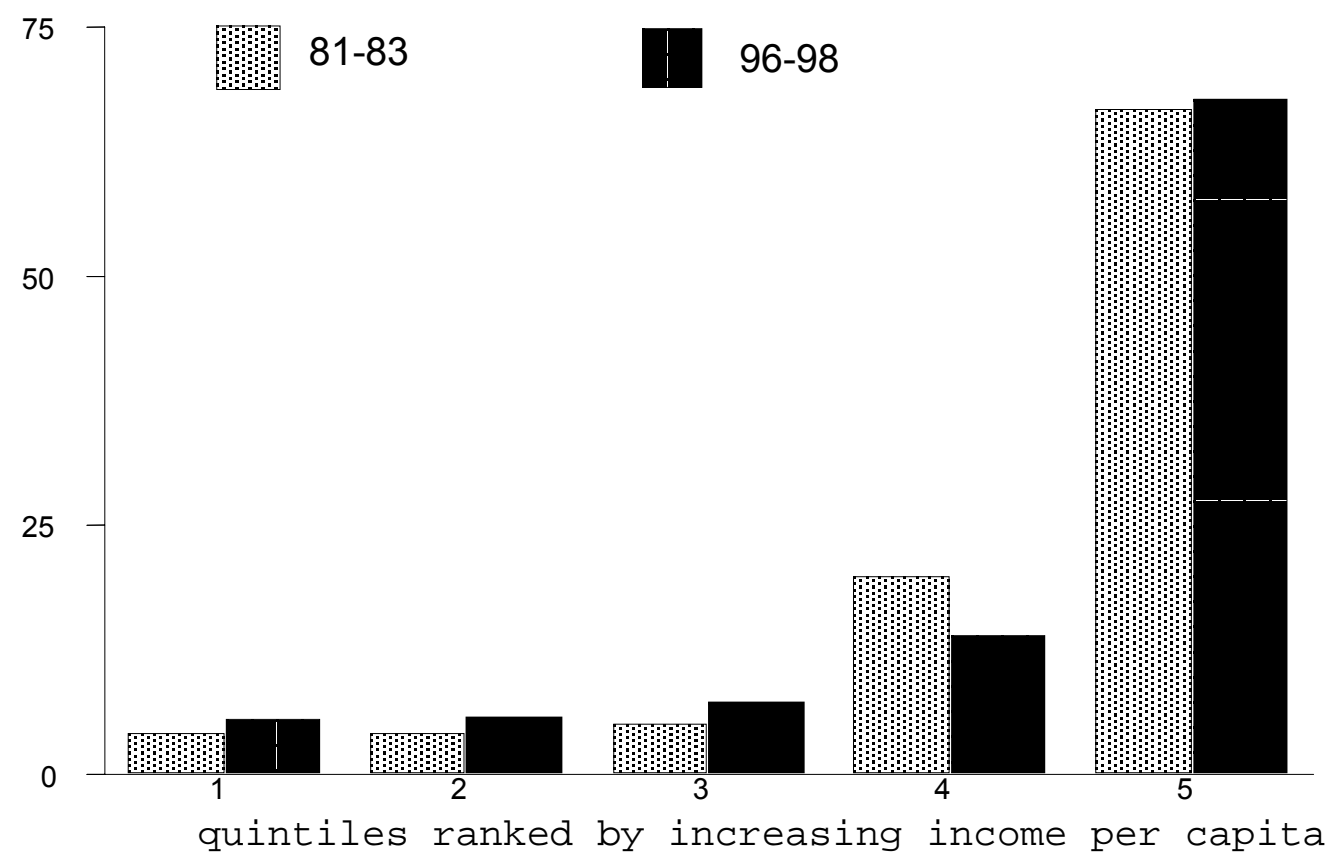




\section{Figure 2: Histograms of exports and imports shares of polluting products}

(a) : Exports

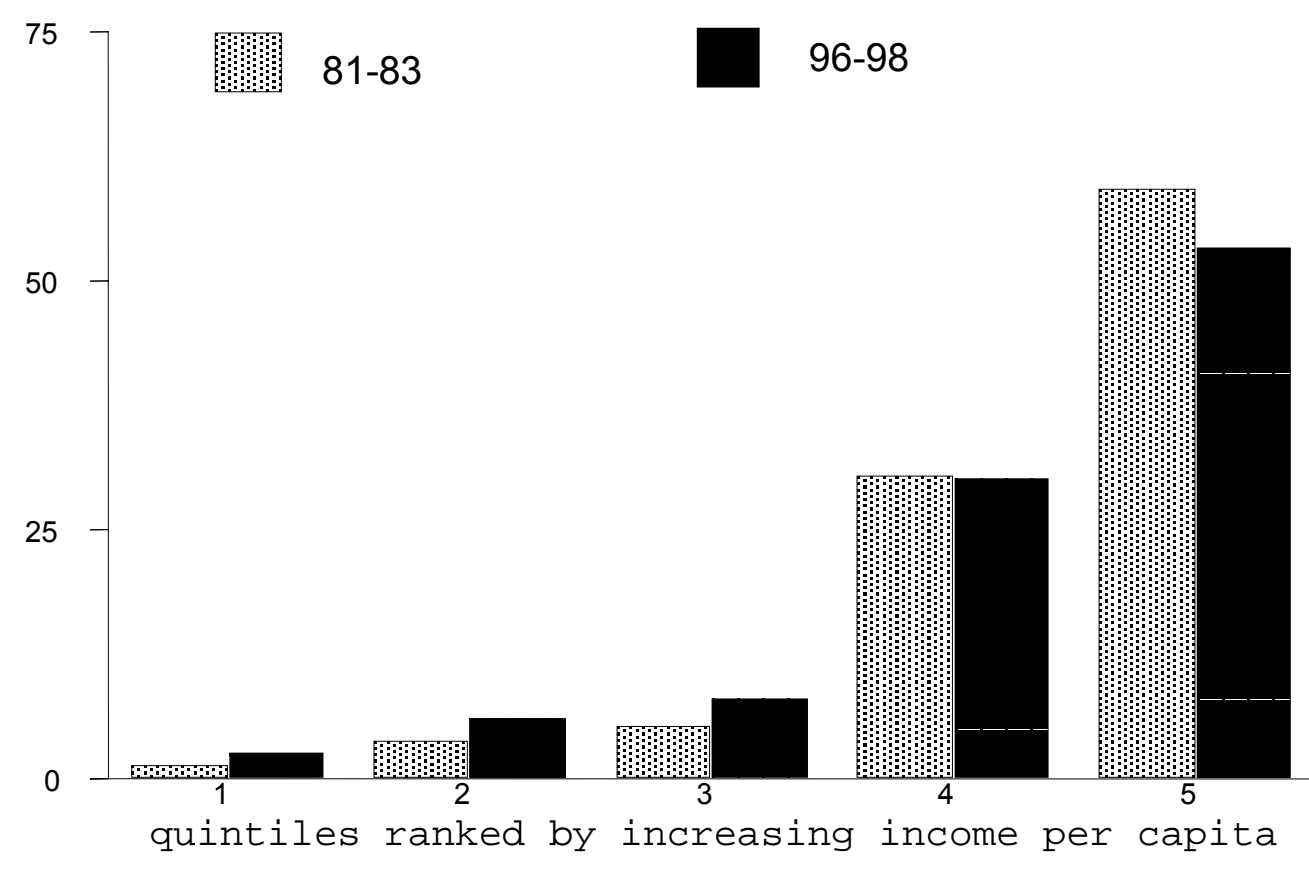

(b) : Imports

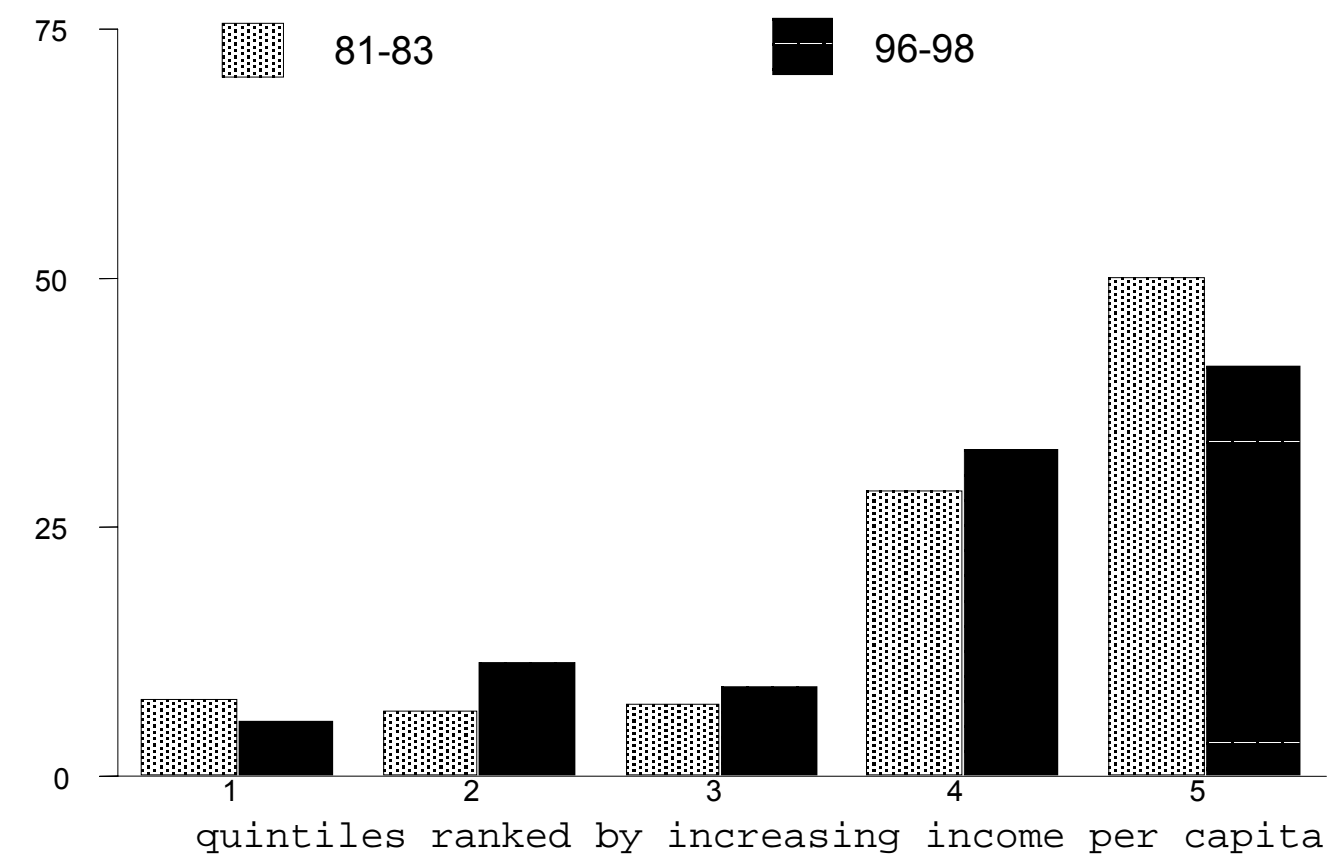

Figure 3: Revealed comparative advantage indices 
in polluting products

(a) Developing Countries

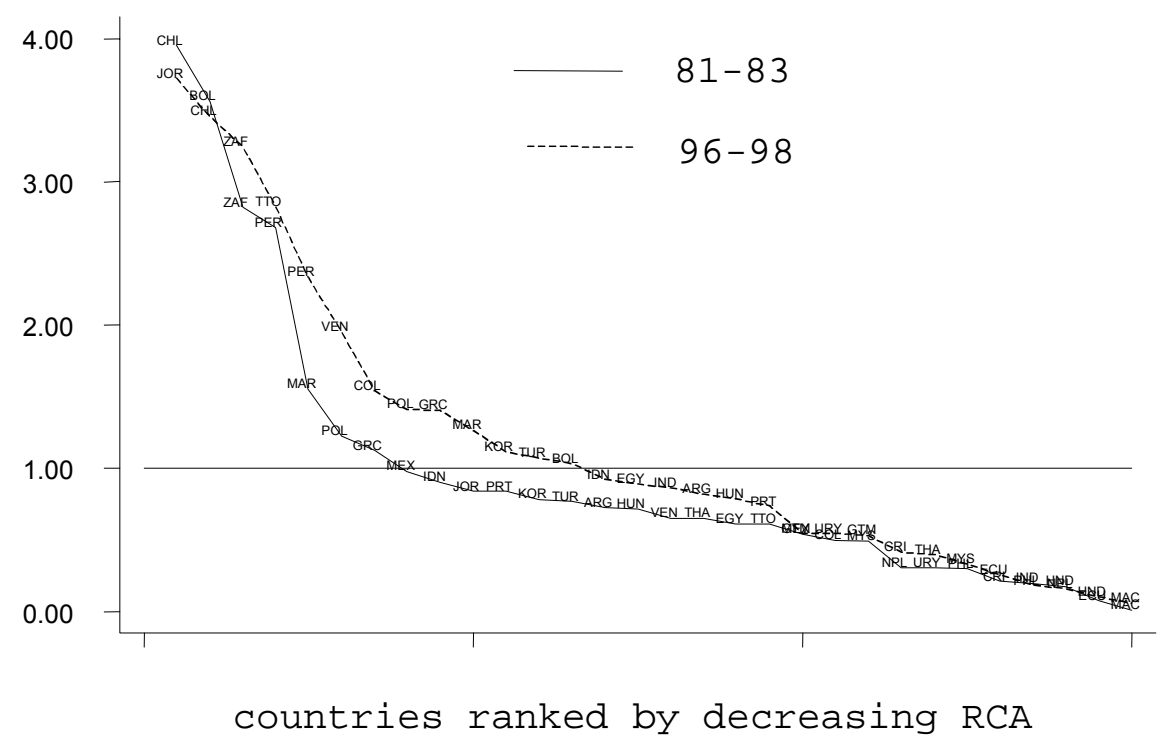

(b) Developed Countries

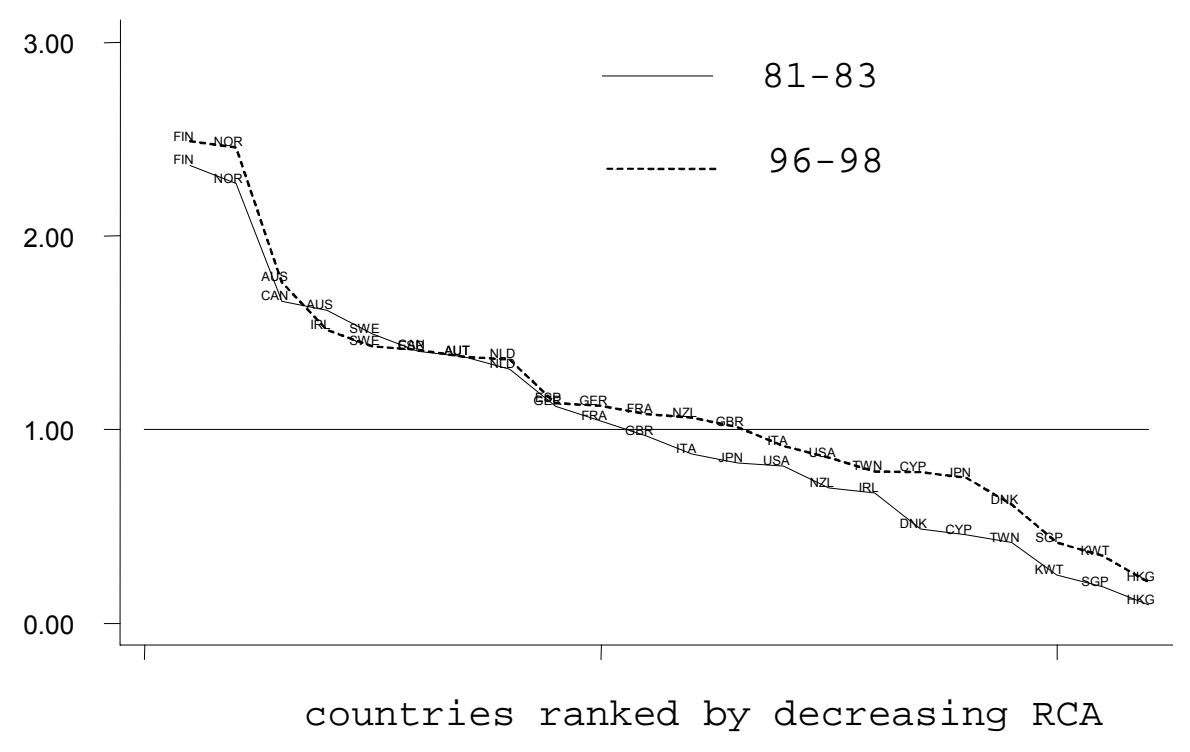




\section{Appendix to \\ Globalization and dirty industries: \\ any pollution haven?}

\section{Jean-Marie Grether \\ Jaime de Melo}

This appendix is in three parts. Section A1 describes the data, transformations and sample representativity. Section A2 gives sectoral tables corresponding to the aggregate results for all polluting products given in tables 2 and 4 in the text. Section A3 does the same for figures 1 to 3 in the text.

\section{A1. Data sources and sample representativity}

The database is extracted from the Trade and Production website of the World Bank (www.worldbank.org/research/trade) and covers the period 1976-1999 for 67 countries. It includes ISIC 3-digit data on imports, exports and mirror exports. For the first five years and for the last year, of the open-sample period, many countries reported missing values. Moreover, mirror exports are only available since 1980. Therefore, a closed sample was defined over the years 1981-1998, with 52 countries ( 5 LINCs, 25 MINCs, 22 HINCs) reporting non-missing values. for the 3digit trade data over this period. Categories of polluting products in table A1.1, and closed-sample countries ${ }^{1}$ are listed in table A1.2.

Table A1.1: Categories of polluting products

\begin{tabular}{l|l} 
ISIC code & Description (rank ${ }^{\mathbf{a}}$ in parenthesis) \\
\hline 341 & Paper and products (6) \\
351 & Industrial chemicals (3) \\
369 & Other non-metallic mineral products (5) \\
371 & Iron and steel (1) \\
372 & Non-ferrous metals (2)
\end{tabular}

a Mani and Wheeler (1999, table 8.1). As in Mani and Wheeler, we have excluded petroleum refineries (353) from the sample.

1 Income groups were defined on the basis of 1991 GNP per capita figures. Following the World Bank cut-off levels, the sample was split into three income groups: low (LINC, income lower than 635 USD), middle (MINC, between 635 and 7910 USD) and high income (HINC, larger than 7910 USD) countries. 
Table A1.2: Countries of the closed sample (1981-1998)

\begin{tabular}{|c|c|c|c|c|c|}
\hline \multicolumn{2}{|c|}{ Low-income } & \multicolumn{2}{|c|}{ Middle-income (ct'd) } & \multicolumn{2}{|c|}{ High-income (ct'd) } \\
\hline EGY & Egypt & MAR & Morocco & DNK & Denmark \\
\hline HND & Honduras & MEX & Mexico & $\mathrm{ESP}$ & Spain \\
\hline IDN & Indonesia & MYS & Malaysia & FIN & Finland \\
\hline IND & India & PER & Peru & FRA & France \\
\hline NPL & Nepal & PHL & Philippines & GBR & United Kingdom \\
\hline \multicolumn{2}{|c|}{ Middle-income } & POL & Poland & GER & Germany \\
\hline ARG & Argentina & PRT & Portugal & HKG & Hong Kong \\
\hline BOL & Bolivia & THA & Thailand & IRL & Ireland \\
\hline $\mathrm{CHL}$ & Chile & TTO & Trinidad and $\mathrm{T}$. & ITA & Italy \\
\hline $\mathrm{COL}$ & Colombia & TUR & Turkey & JPN & Japan \\
\hline CRI & Costa Rica & URY & Uruguay & KWT & Kuwait \\
\hline ECU & Ecuador & VEN & Venezuela & NLD & Netherlands \\
\hline GRC & Greece & $\mathrm{ZAF}$ & South Africa & NOR & Norway \\
\hline GTM & Guatemala & \multicolumn{2}{|c|}{ High-income } & NZL & New Zealand \\
\hline HUN & Hungary & AUS & Australia & $\mathrm{SGP}$ & Singapore \\
\hline JOR & Jordan & AUT & Austria & SWE & Sweden \\
\hline KOR & Korea (Rep.of) & CAN & Canada & TWN & Taiwan \\
\hline MAC & Macau & CYP & Cyprus & USA & United States \\
\hline
\end{tabular}

\section{Sample representativity}

\section{a) open and closed sample}

With respect to the open sample, and using the 1995-96 average trade shares (the years with the maximum amount of non-missing values), the closed sample represents about 95\% of the open sample trade.

Regarding the representativity of the open sample itself, this was estimated using world trade data reported by the World Bank (Economic Indicators 2001). Results are shown in Table A1.3. These figures may appear quite low. However, it should be kept in mind that world trade figures used in these calculations are estimated themselves. As a result, even in the original World Bank data, the sum of exports and imports over 207 countries represent less than 100\% of world totals (see last two columns of table A1.3). 
Table A1.3: Representativity of the open and the closed sample (\%, using reported world totals by the World Bank)

\begin{tabular}{l|rrrrrr} 
& \multicolumn{2}{|c}{$\begin{array}{c}\text { open sample } \\
\text { Exports }\end{array}$} & $\begin{array}{c}\text { closed sample } \\
\text { clorts }\end{array}$ & Exports & original source \\
& Imports & Exports & Imports \\
\hline 1981 & 48.8 & 44.3 & 48.7 & 43.7 & 81.5 & 81.3 \\
1990 & 58.9 & 59.5 & 57.3 & 57.9 & 86.4 & 86.2 \\
1998 & 63.6 & 66.3 & 60.5 & 63.6 & 94.5 & 94.5
\end{tabular}

a) sum over the 207 countries reported in the World Bank data base

Source: sample data and World Bank Economic Indicators, 2001.

\section{b) income groups}

Similar world totals were not available for income groups. In this case, world totals were estimated by the sum of exports or imports over all the countries available in the World Bank source. To account for a maximum number of non-missing reporters, these calculations, whose results appear in table A1.4, are limited to year $1998^{2}$.

Table A1.4: Representativity of the open and the closed sample by income groups

(\%, 1998, using calculated world totals ${ }^{a}$ )

\begin{tabular}{l|llll} 
& \multicolumn{2}{|c}{ open sample } & \multicolumn{2}{c}{ closed sample } \\
& Exports & Imports & Exports & Imports \\
\hline LINCs & 64.6 & 61.4 & 52.1 & 46.8 \\
MINCs & 74.9 & 72.2 & 56.4 & 56.1 \\
HINCs & 92.8 & 92.9 & 92.8 & 92.9 \\
All & 88.3 & 87.5 & 84.1 & 83.7
\end{tabular}

a) sum over the 207 countries reported in the World Bank data base

Source: sample data and World Bank Economic Indicators, 2001.

Generally speaking, representativity is larger for HINCs (and of course for the open sample). However, even for LINCs and MINCs in the closed sample, the coverage of world trade is larger than 50\% (except for LINCs imports).

\footnotetext{
2 Accordingly, it is a more recent classification of countries by income groups (based on 1999 GNP figures) that is applied in this particular table.
} 


\section{c) polluting products}

Similar calculations were not possible for polluting products, as world trade data were not available at this level of disaggregation. However, a very crude indicator of the representativity of the sample for these products is simply the ratio of imports over exports, which should be equal to 1.0 in case of complete coverage. These figures, along with their standardized value obtained by dividing them by the import/export ratio for all products in the sample, are reported in table A1.5.

Table A1.5: Imports over exports ratios

\begin{tabular}{l|cccc} 
& \multicolumn{2}{|c}{ polluting } & all products & (1)/(2) \\
& products (1) & (2) & \\
\hline 1981 & 0.96 & 0.92 & 1.04 \\
1990 & 1.11 & 1.03 & 1.08 \\
1998 & 1.14 & 1.03 & 1.10
\end{tabular}

Overall, the ratio is reasonably close to one, which suggests an acceptable level of representativity for polluting products. 


\section{A2. Sectoral results: tables}

Table A2.1: Shares of developing countries in world trade

Paper and products (ISIC $=341)$

\begin{tabular}{|c|c|c|c|c|c|c|}
\hline & \multicolumn{2}{|c|}{ polluting products } & \multicolumn{2}{|c|}{ all products } & \multicolumn{2}{|c|}{$\begin{array}{c}\text { revealed } \\
\text { comparative }\end{array}$} \\
\hline & $\begin{array}{c}\text { exports } \\
\text { (1) }\end{array}$ & $\begin{array}{l}\text { imports } \\
\text { (2) }\end{array}$ & $\begin{array}{c}\text { exports } \\
\text { (3) }\end{array}$ & $\begin{array}{l}\text { imports } \\
\text { (4) }\end{array}$ & $\begin{array}{c}\text { advantage } \\
(1) /(3)\end{array}$ & $\begin{array}{c}\text { disad- } \\
\text { vantage } \\
(2) /(4)\end{array}$ \\
\hline 1981-83 & 3.70 & 12.70 & 9.40 & 15.73 & 0.39 & 0.81 \\
\hline $1996-98$ & 9.55 & 19.92 & 15.93 & 18.67 & 0.60 & 1.07 \\
\hline \multirow[t]{4}{*}{ rate of growth } & 6.53 & 3.05 & 3.58 & 1.15 & & \\
\hline & \multicolumn{2}{|c|}{ Industrial } & chemicals & $($ ISIC $=351)$ & & \\
\hline & \multicolumn{2}{|c|}{ polluting products } & \multicolumn{2}{|c|}{ all products } & \multicolumn{2}{|c|}{$\begin{array}{c}\text { revealed } \\
\text { comparative }\end{array}$} \\
\hline & $\begin{array}{c}\text { exports } \\
\text { (1) }\end{array}$ & $\begin{array}{c}\text { imports } \\
\text { (2) }\end{array}$ & $\begin{array}{c}\text { exports } \\
\text { (3) }\end{array}$ & $\begin{array}{c}\text { imports } \\
\text { (4) }\end{array}$ & $\begin{array}{l}\text { advantage } \\
(1) /(3)\end{array}$ & $\begin{array}{l}\text { disad- } \\
\text { vantage } \\
(2) /(4)\end{array}$ \\
\hline $1981-83$ & 5.11 & 21.55 & 9.40 & 15.73 & 0.54 & 1.37 \\
\hline $1996-98$ & 12.12 & 24.33 & 15.93 & 18.67 & 0.76 & 1.30 \\
\hline rate of growth & 5.92 & 0.82 & 3.58 & 1.15 & & \\
\hline
\end{tabular}

Other non-metallic mineral products (ISIC=369)

polluting products all products revealed

comparative

exports imports exports imports advantage disad-

\begin{tabular}{lrrrrrr} 
& $(\mathbf{1})$ & $\mathbf{( 2 )}$ & \multicolumn{1}{c}{$(\mathbf{3})$} & $\mathbf{( 4 )}$ & $\mathbf{( 1 ) / ( 3 )}$ & $\mathbf{( 2 ) / ( 4 )}$ \\
\hline $\mathbf{1 9 8 1 - 8 3}$ & 11.42 & 22.33 & 9.40 & 15.73 & 1.22 & 1.42 \\
$\mathbf{1 9 9 6 - 9 8}$ & 16.28 & 19.16 & 15.93 & 18.67 & 1.02 & 1.03 \\
rate of growth & 2.39 & -1.02 & 3.58 & 1.15 & &
\end{tabular}

Iron and steel (ISIC=371)

polluting products all products revealed

comparative

exports imports exports imports advantage disad-

\begin{tabular}{|c|c|c|c|c|c|c|}
\hline & (1) & (2) & (3) & (4) & $(1) /(3)$ & $\begin{array}{l}\text { vantage } \\
(2) /(4)\end{array}$ \\
\hline 1981-83 & 9.09 & 23.63 & 9.40 & 15.73 & 0.97 & 1.50 \\
\hline $1996-98$ & 18.38 & 26.85 & 15.93 & 18.67 & 1.15 & 1.44 \\
\hline rate of growth & 4.81 & 0.86 & 3.58 & 1.15 & & \\
\hline
\end{tabular}

Non-ferrous metals (ISIC $=372$ )

polluting products all products revealed

comparative

exports imports exports imports advantage disad-

$\begin{array}{llllll}\text { (1) } & \text { (2) } & \text { (3) } & \text { (4) } & \text { (1) /(3) } & \text { (2) / (4) }\end{array}$

\begin{tabular}{lrrrrrr} 
& $(1)$ & $(2)$ & \multicolumn{1}{c}{$(\mathbf{3})$} & \multicolumn{1}{c}{$(\mathbf{4})$} & (1)/(3) & $(\mathbf{2}) /(4)$ \\
\hline $\mathbf{1 9 8 1 - 8 3}$ & 24.01 & 10.31 & 9.40 & 15.73 & 2.56 & 0.66 \\
$\mathbf{1 9 9 6 - 9 8}$ & 22.91 & 17.88 & 15.93 & 18.67 & 1.44 & 0.96 \\
rate of growth & -0.31 & 3.73 & 3.58 & 1.15 & &
\end{tabular}


Table A2.2: Decomposition of aggregate change in RCA for LDCs

\begin{tabular}{l|ccc} 
ISIC & $\begin{array}{c}\text { total change } \\
\text { in RCA }\end{array}$ & $\begin{array}{c}\text { composition } \\
\text { effect }\end{array}$ & $\begin{array}{c}\text { structural } \\
\text { effect }\end{array}$ \\
\hline $\mathbf{3 4 1}$ & 0.206 & -0.060 & 0.266 \\
$\mathbf{3 5 1}$ & 0.216 & -0.087 & 0.303 \\
$\mathbf{3 6 9}$ & -0.193 & -0.301 & 0.108 \\
$\mathbf{3 7 1}$ & 0.186 & -0.260 & 0.446 \\
$\mathbf{3 7 2}$ & -1.118 & -0.529 & -0.589
\end{tabular}

Table A2.3 : Gravity equation: Hausman-Taylor estimates Dependent variable: $M_{i j t}$ (imports of $i$ from $j$ in period $t$ )

\begin{tabular}{|c|c|c|c|c|c|c|}
\hline \multirow[b]{2}{*}{ Independent } & \multirow[b]{2}{*}{ POL2-HT } & \multirow[b]{2}{*}{$341^{\mathrm{b}}$} & \multicolumn{4}{|c|}{$\mathbf{M}_{i j t}$} \\
\hline & & & $351^{c}$ & 369 & 371 & 372 \\
\hline $\ln \left(Y_{i t}\right)$ & $1.50 * \star$ & $1.26 * \star$ & $1.27 \star \star$ & $1.69 * \star$ & $1.82 \star \star$ & $1.91 * \star$ \\
\hline $\ln \left(Y_{j t}\right)$ & $\begin{array}{l}(19.4) \\
0.92 * *\end{array}$ & $\begin{array}{c}(12.6) \\
0.58\end{array}$ & $\begin{array}{l}(16.39) \\
1.86^{* *}\end{array}$ & $\begin{array}{c}(15.4) \\
-0.58 * *\end{array}$ & $\begin{array}{l}(16.5) \\
-0.32 *\end{array}$ & $\begin{array}{l}(17.8) \\
-0.16\end{array}$ \\
\hline & $(10.9)$ & $(5.0)$ & $(21.8)$ & $(5.0)$ & $(2.5)$ & $(1.3)$ \\
\hline $\ln \left[\left(Y_{i t} / N_{i t}\right)-\right.$ & 0.007 & $0.08 *$ & 0.03 & $0.12 * \star$ & $0.11 * \star$ & -0.04 \\
\hline$\left.\left(\mathbf{Y}_{j t} / \mathbf{N}_{j t}\right)\right]$ & $(0.3)$ & $(2.0)$ & $(1.1)$ & $(3.5)$ & $(2.7)$ & $(1.1)$ \\
\hline Ln $\operatorname{DIST}_{i j}$ & $\begin{array}{l}-1.12 * \star \\
(17.7)\end{array}$ & $\begin{array}{l}-1.40 * * \\
(14.4)\end{array}$ & $\begin{array}{l}-1.23 * * \\
(19.1)\end{array}$ & $\begin{array}{l}-1.21 * * \\
(12.9)\end{array}$ & $\begin{array}{l}-1.12 * \star \\
(7.9)\end{array}$ & $\begin{array}{c}-0.95 * \star \\
(6.8)\end{array}$ \\
\hline $\mathrm{BOR}_{\mathrm{ij}}$ & $\begin{array}{c}1.30 * * \\
(5.5)\end{array}$ & $\begin{array}{l}1.68 * * \\
(4.01)\end{array}$ & $\begin{array}{c}1.15 * * \\
(4.6)\end{array}$ & $\begin{array}{c}1.70 * * \\
(4.2)\end{array}$ & $\begin{array}{c}0.96 * * \\
(2.8)\end{array}$ & $\begin{array}{l}0.87 \\
(1.6)\end{array}$ \\
\hline$L L_{i}$ & $\begin{array}{l}0.49 \\
(1.66)\end{array}$ & $\begin{array}{l}0.52 \\
(1.0)\end{array}$ & $\begin{array}{r}-0.28 \\
(0.9)\end{array}$ & $\begin{array}{c}1.76 * \star \\
(3.4)\end{array}$ & $\begin{array}{l}2.79 \star \star \\
(4.23)\end{array}$ & $\begin{array}{l}2.26 * * \\
(3.3)\end{array}$ \\
\hline$L L_{j}$ & $\begin{array}{l}-0.42 * * \\
(1.22)\end{array}$ & $\begin{array}{l}-2.48 * * \\
(3.8)\end{array}$ & $\begin{array}{l}-1.99 * * \\
(5.4)\end{array}$ & $\begin{array}{c}-4.39 * * \\
(6.9)\end{array}$ & $\begin{array}{l}-3.79 * * \\
(4.25)\end{array}$ & $\begin{array}{l}-2.48 * * \\
(3.3)\end{array}$ \\
\hline In INF $_{\text {it }}$ & $\begin{array}{l}0.46 * * \\
(6.43)\end{array}$ & $\begin{array}{c}0.48 * * \\
(5.1)\end{array}$ & $\begin{array}{c}0.43 * * \\
(6.1)\end{array}$ & $\begin{array}{c}0.98 * * \\
(9.3)\end{array}$ & $\begin{array}{c}0.51 * * \\
(4.4)\end{array}$ & $\begin{array}{c}0.55 * * \\
(4.9)\end{array}$ \\
\hline Ln $I N F_{j t}$ & $\begin{array}{l}0.64 * \star \\
(7.7)\end{array}$ & $\begin{array}{c}1.19 * \star \\
(9.9)\end{array}$ & $\begin{array}{c}0.26 * \star \\
(3.0)\end{array}$ & $\begin{array}{l}2.22 \star \star \\
(18.6)\end{array}$ & $\begin{array}{c}1.43 * \star \\
(9.9)\end{array}$ & $\begin{array}{l}0.15 \\
(1.2)\end{array}$ \\
\hline In $R_{E} R_{i j t}$ & $\begin{array}{r}-0.40 * \\
(14.3)\end{array}$ & $\begin{array}{c}-0.57 * \star \\
(14.3)\end{array}$ & $\begin{array}{c}-0.35 * * \\
(12.6)\end{array}$ & $\begin{array}{c}-0.66 * \star \\
(16.3)\end{array}$ & $\begin{array}{c}-0.71 * * \\
(16.6)\end{array}$ & $\begin{array}{c}-0.19 * * \\
(5.1)\end{array}$ \\
\hline Number of obs (NT) & 30345 & 21831 & 28087 & 20907 & 21122 & 21591 \\
\hline Number of bilateral (N) & 2300 & 2017 & 2240 & 1970 & 1938 & 1956 \\
\hline $\mathrm{R}^{2}$ & 0.52 & 0.51 & 0.52 & 0.44 & 0.51 & 0.35 \\
\hline 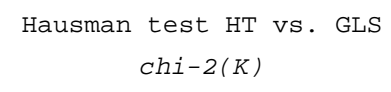 & $\begin{array}{c}614 \cdot 7^{* \star} \\
\text { Chi-2(25) }\end{array}$ & $\begin{array}{c}413.1^{* *} \\
\operatorname{Chi}-2(25)\end{array}$ & $\begin{array}{c}589.6^{* *} \\
\operatorname{Chi}-2(25)\end{array}$ & $\begin{array}{c}13.7 * * \\
\text { Chi-2(25) }\end{array}$ & $\begin{array}{c}97.9 * * \\
\text { Chi-2(25) }\end{array}$ & $\begin{array}{c}182.5^{* *} \\
\text { Chi-2(25) }\end{array}$ \\
\hline $\begin{array}{l}\text { * and *: signific } \\
\text { the correspondent } \\
\text { Time dummy variabl } \\
\text { Random effect esti } \\
\mathrm{Y}_{j}\left(\mathrm{~N}_{\mathrm{j}}\right) \text { ) }\end{array}$ & $\begin{array}{l}\text { ht at } 99 \\
\text { befficie } \\
\text { s and } \\
\text { ates (en }\end{array}$ & $\begin{array}{l}\text { istant } \\
\text { ggenous }\end{array}$ & $\begin{array}{l}\mathrm{rm} \text { not } \\
\text { ariable }\end{array}$ & $\begin{array}{l}\text { ported } \\
: Y_{i} a\end{array}$ & $Y_{j}$ and & ${ }_{i} / \mathrm{N}_{\mathrm{i}}-$ \\
\hline
\end{tabular}




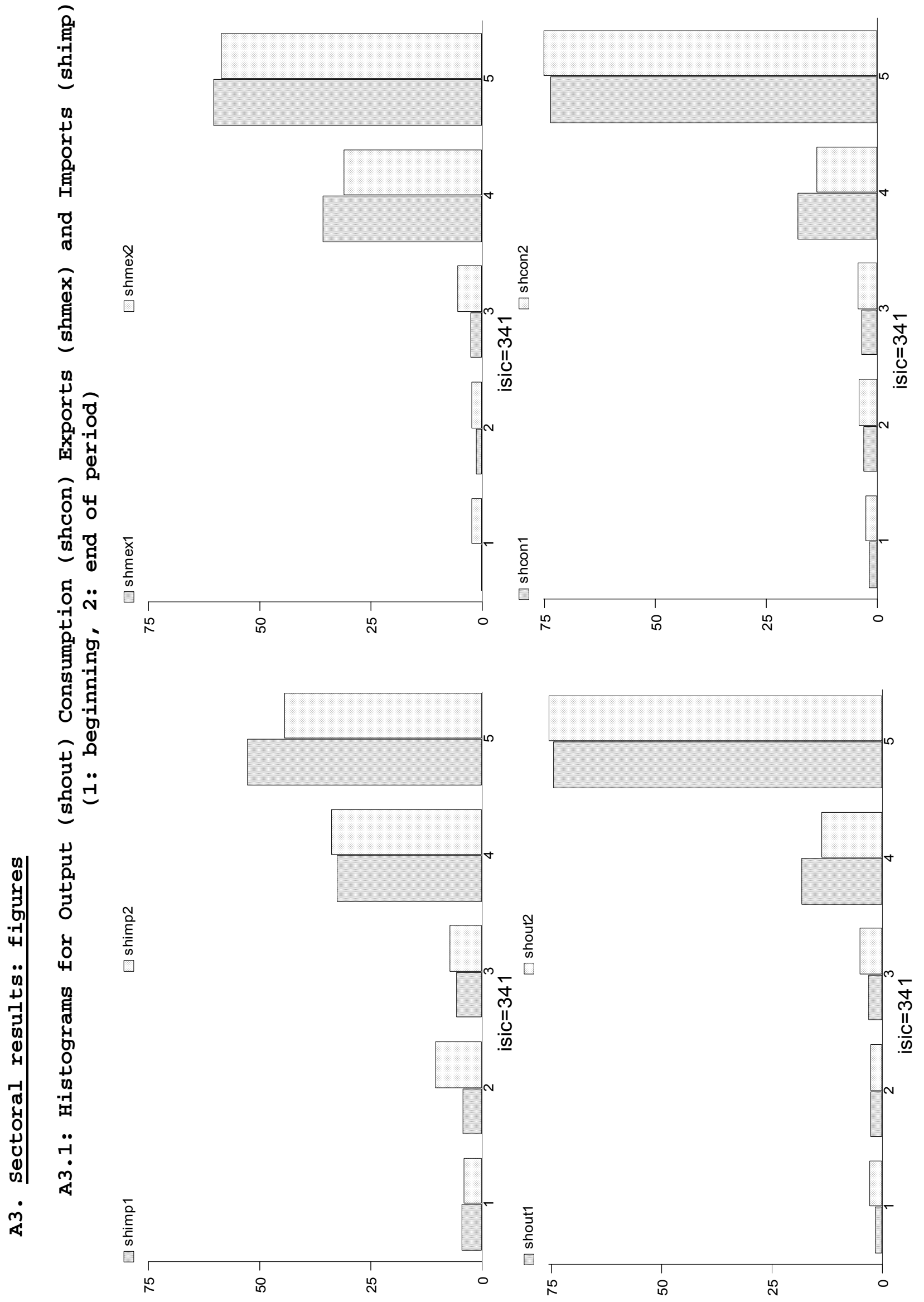


号
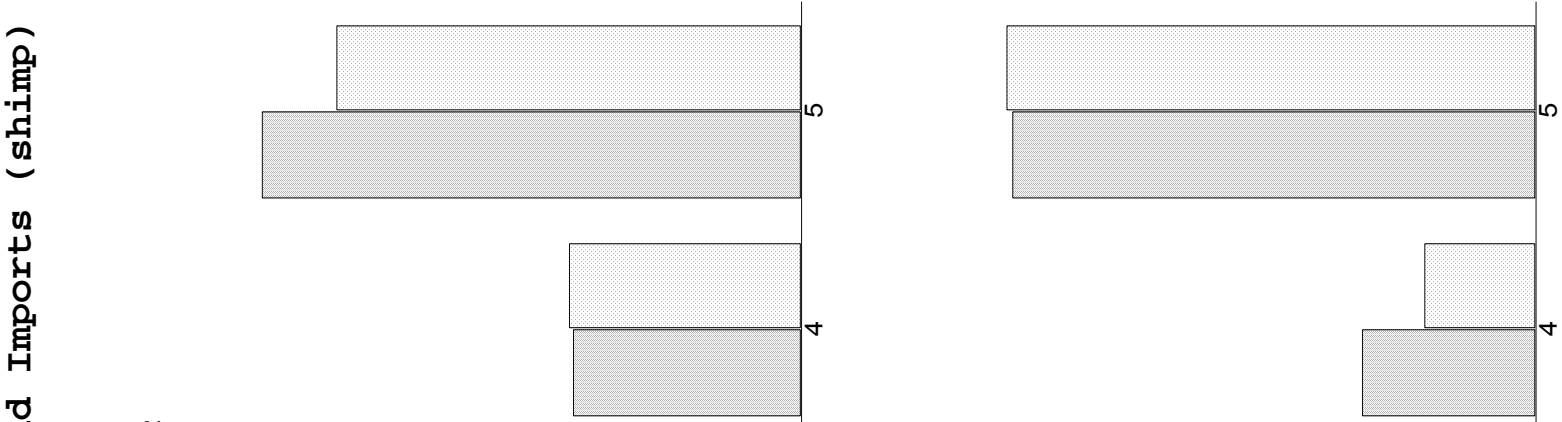

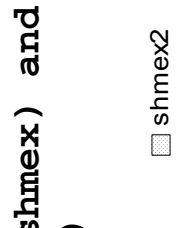

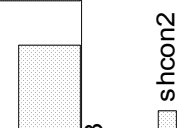

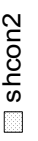

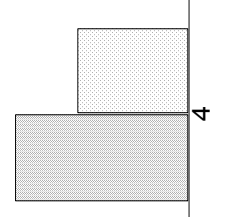

ชิ

包㕵

ณ. U

图
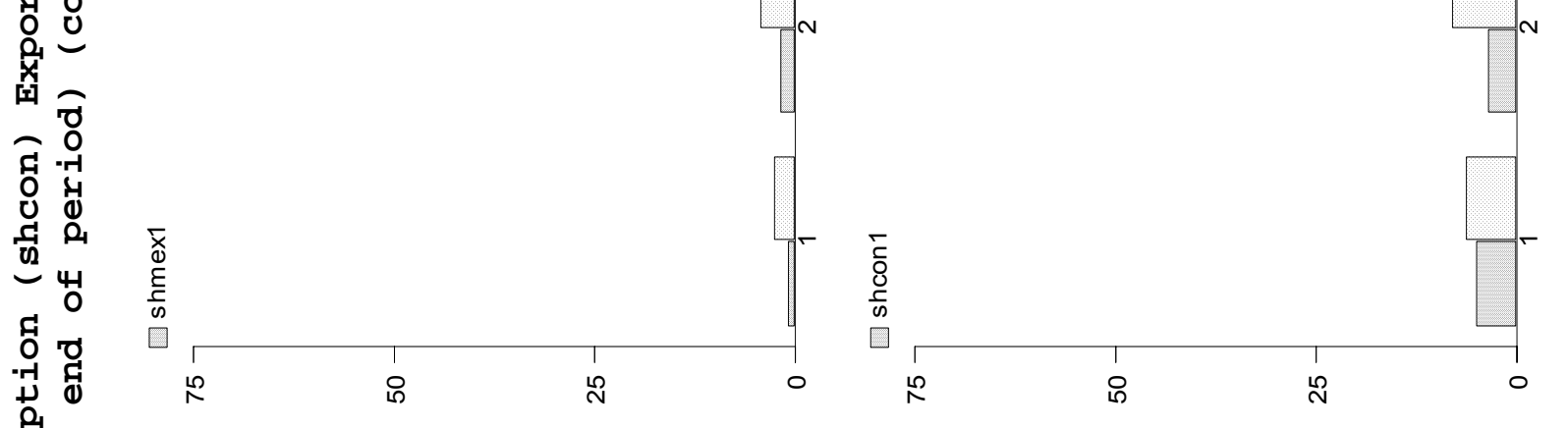

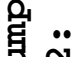

疍 $N$

¿̊

0 .

กิ

ว

v.

$+\ddot{r}$

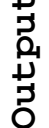

H

?

\%

on

8

in

.

r.
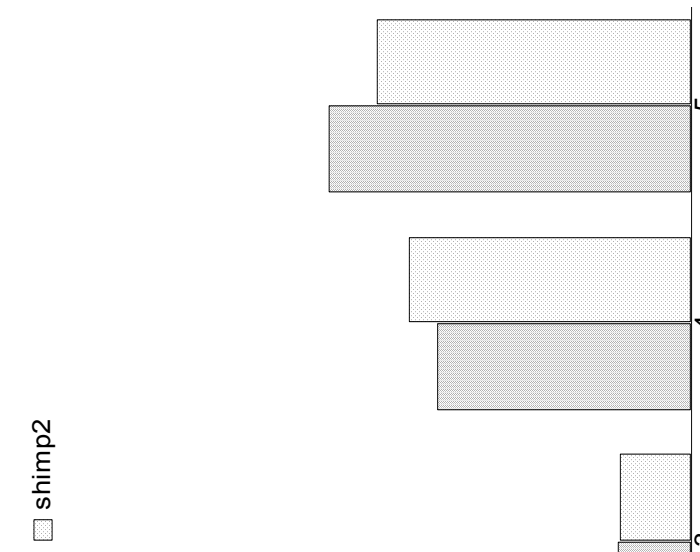

을
II
$\frac{0}{n}$
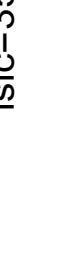


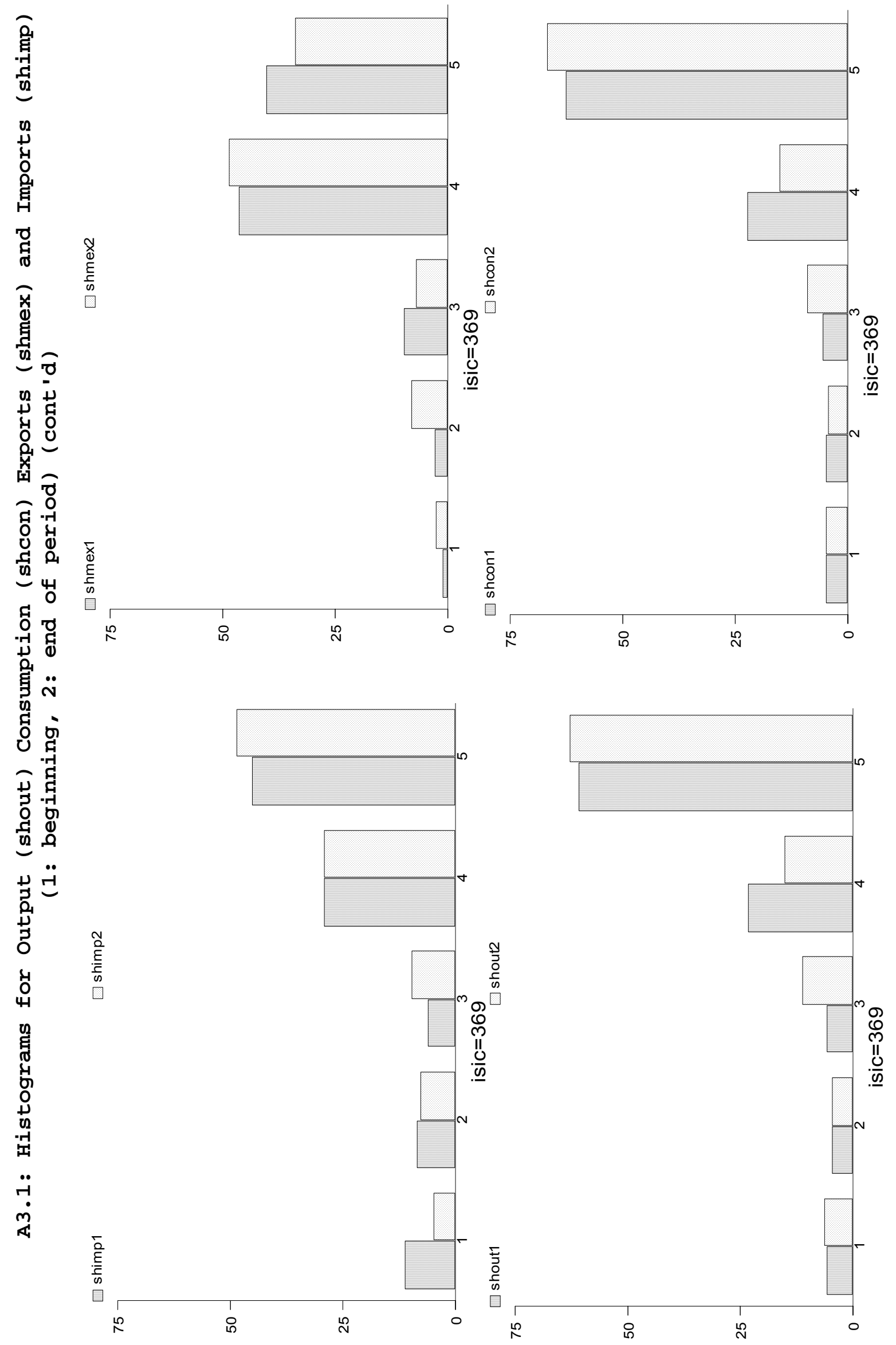




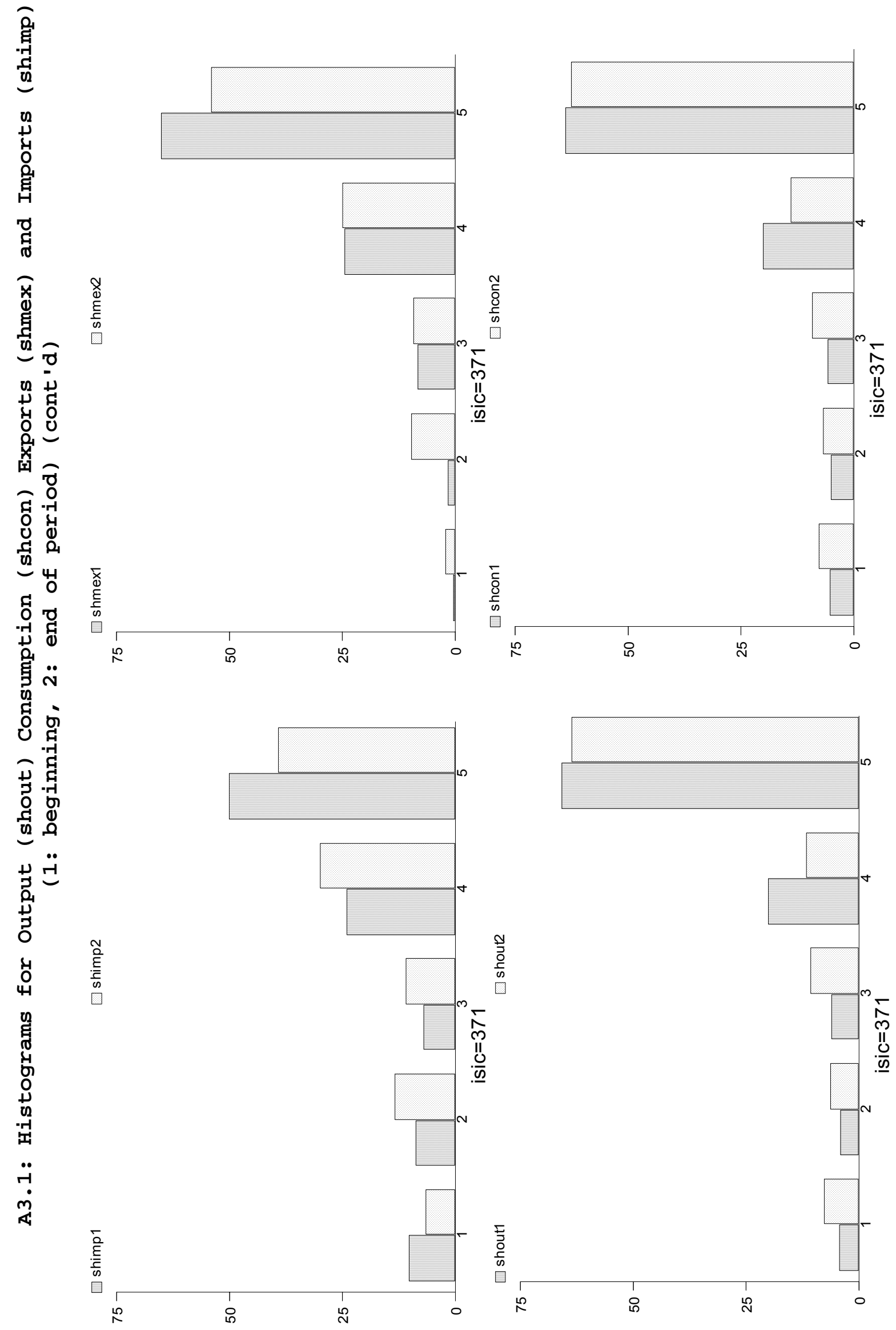




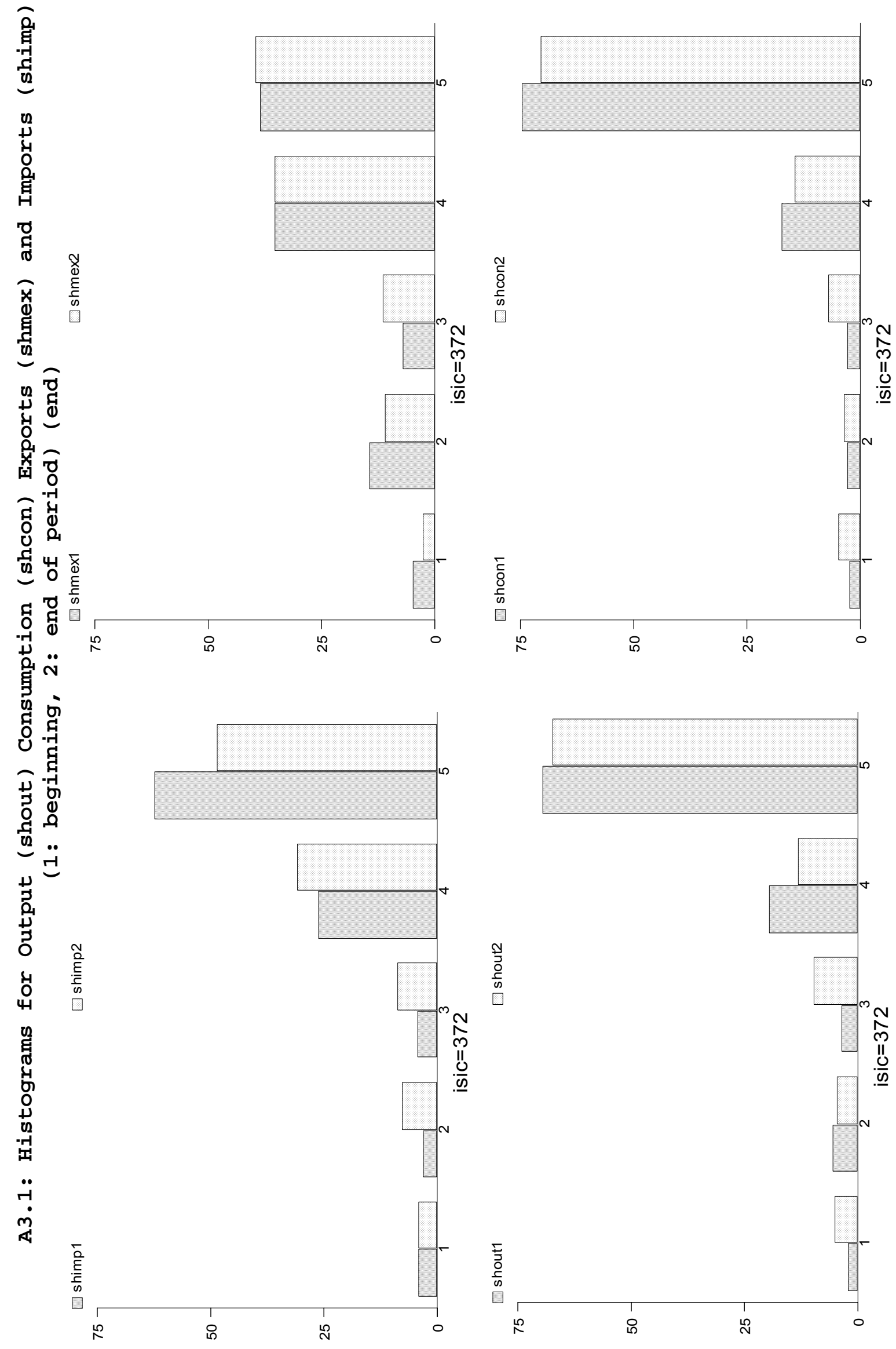


A3.2: Beginning(1) and End(2) of period RCAs, by country group $\operatorname{ISIC}=341$
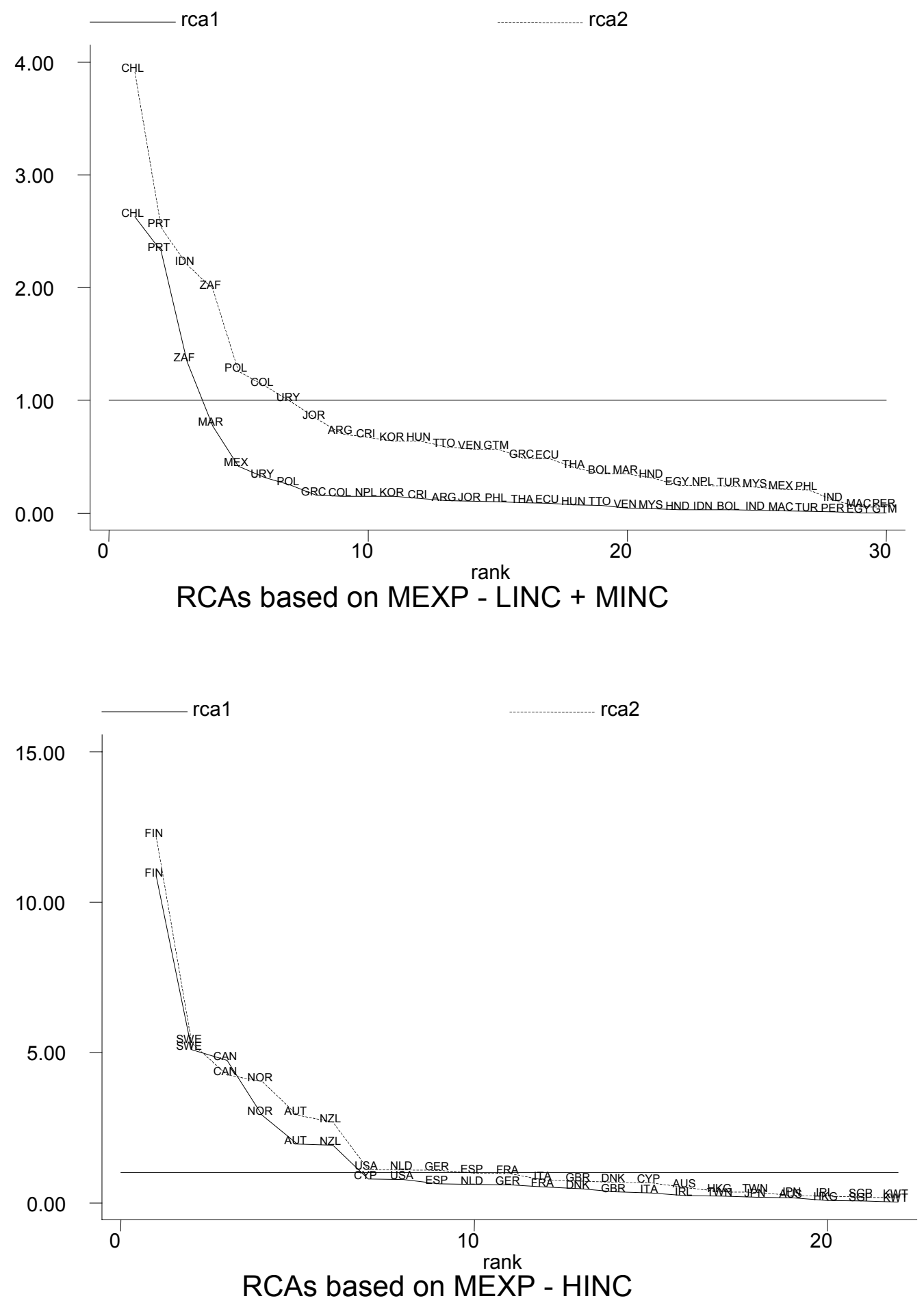
A3.2: Beginning(1) and End(2) of period RCAs, by country group (cont 'd)
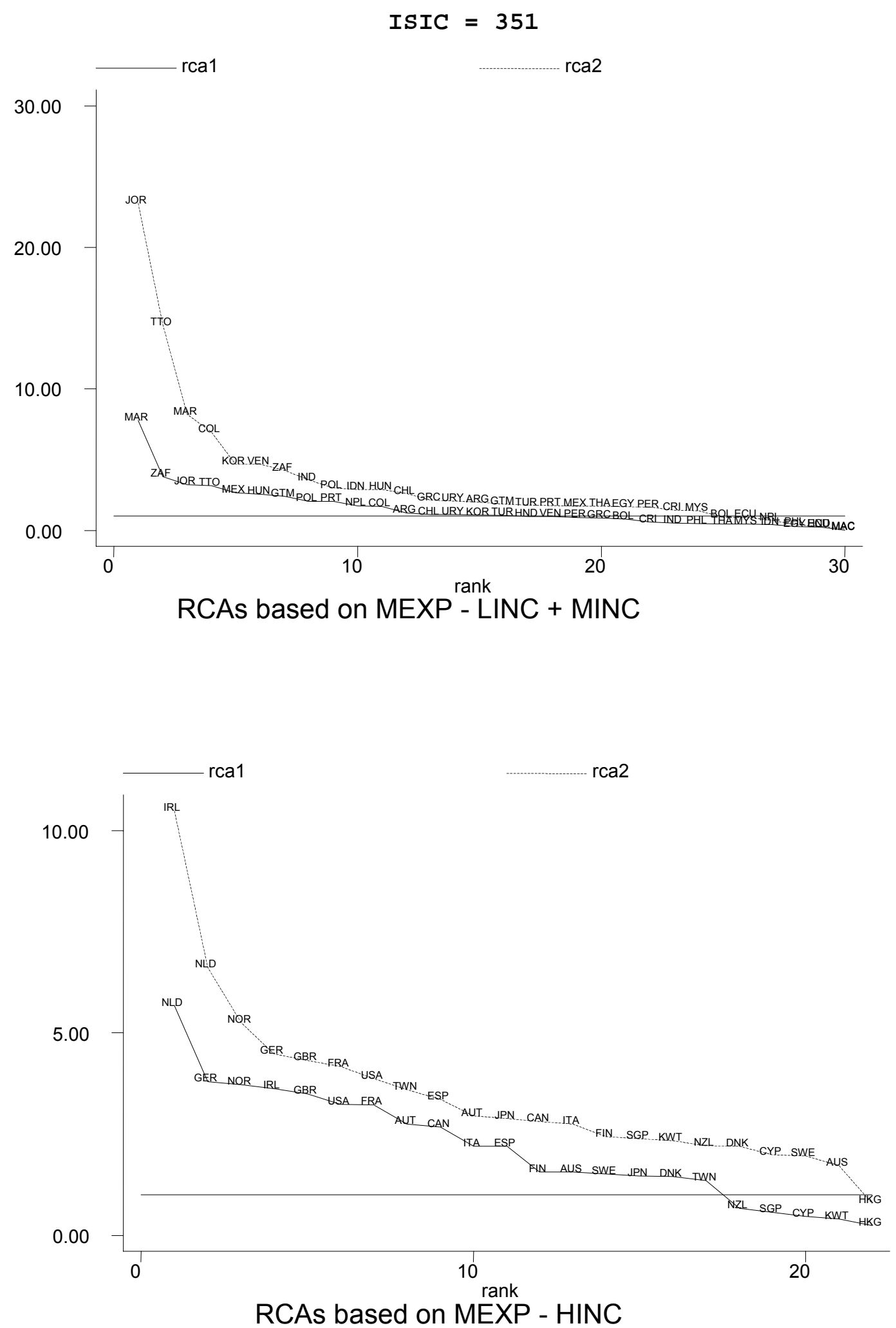
A3.2: Beginning(1) and End(2) of period RCAs, by country group (cont 'd)

$$
\text { ISIC }=369
$$
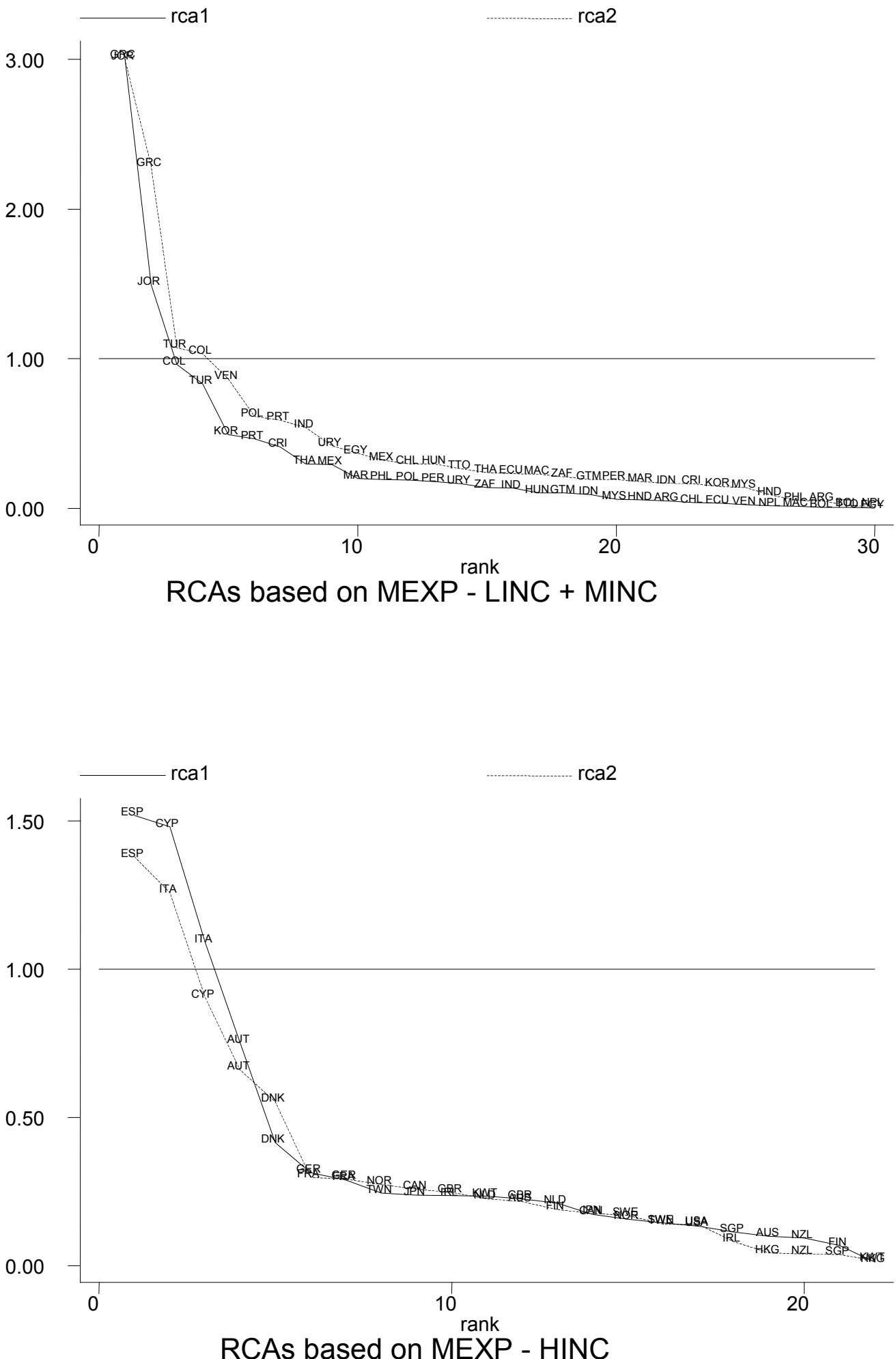
A3.2: Beginning(1) and End(2) of period RCAs, by country group (cont 'd)

$$
\text { ISIC }=371
$$
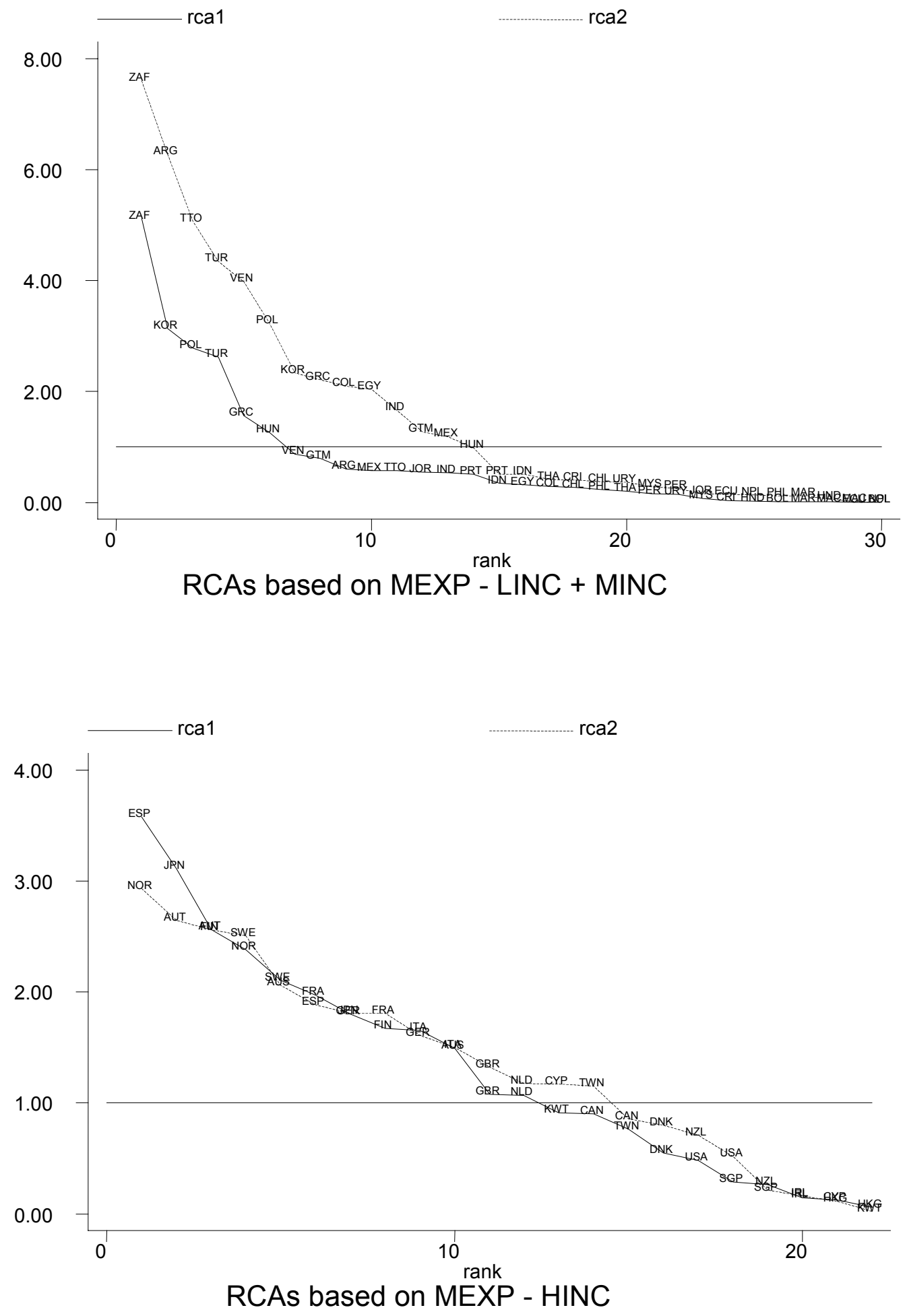
A3.2: Beginning(1) and End(2) of period RCAs, by country group (end)
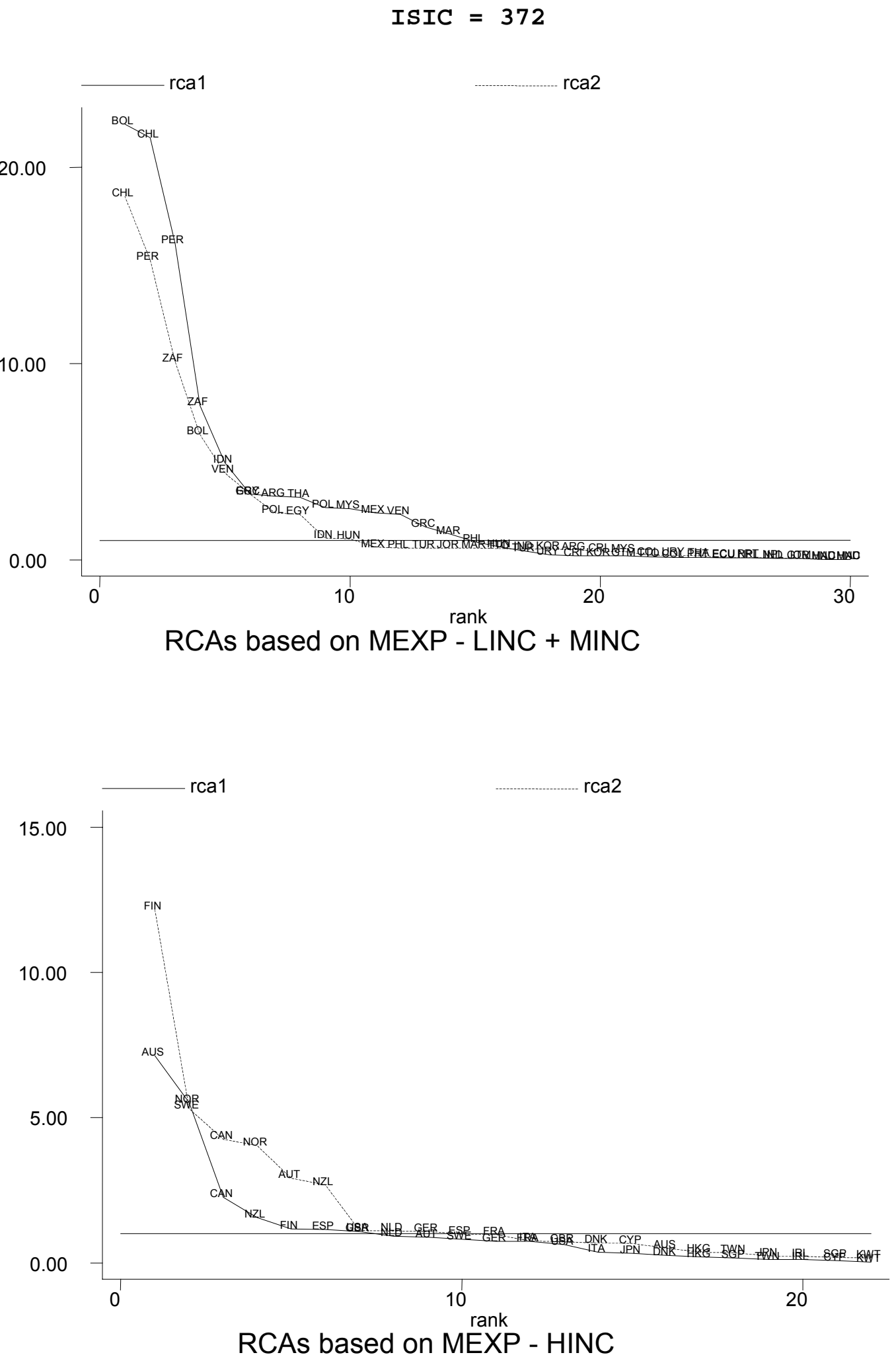